\title{
VISUALIDADES: RESTITUIÇÃO E INSERÇÃO SOCIAL
}

\author{
Nilson Almino de Freitas ${ }^{1}$
}

\section{Considerações iniciais ${ }^{2}$}

O Visualidades é um evento único, na sua forma e na sua definição. Faz a integração entre artes visuais e diferentes tipos de pesquisa e saberes. O diferencial é que se afasta dos muros da "erudição" artística e acadêmica e vai dialogar com as comunidades pobres dos bairros periféricos, espalhando-se pelas cidades envolvidas. As artes visuais produzidas no campo acadêmico vão até aqueles que não têm acesso nenhum, ou parcial, a estas linguagens. Os trabalhos nas linguagens do documentário, da fotografia, do desenho, da pintura e das instalações apresentados, são selecionados via edital lançado geralmente em setembro de cada ano, e contemplam também aqueles que passaram pelas atividades de realização de artes visais promovidas pelo Laboratório das Memórias e das Práticas Cotidianas - LABOME da Universidade Estadual Vale do Acaraú - UVA, e parceiros ${ }^{3}$.

São selecionados também obras de demais artistas do Brasil e do exterior que apresentam suas artes em mostras descentralizadas na região metropolitana de Sobral, no estado do Ceará, e, em 2017, no Rio de Janeiro. No ano de 2016, foram 21 lugares contemplados com as mostras descentralizadas, sendo cinco cidades próximas de Sobral. Tais lugares se consistiram em escolas públicas de Ensino Fundamental e Médio, bairros das periferias das cidades, entidades sociais, como ONGs e CRAS. Em 2017, foram 33 lugares, incluindo três na cidade do Rio de Janeiro, somando 12 cidades e dois estados do país nas mostras descentralizadas, 62 trabalhos de artes visuais apresentados, de 7 países diferentes. Estiveram, aproximadamente, 2000 pessoas envolvidas.

Os produtores que participam presencialmente do evento têm a oportunidade de discutir sobre sua arte com o público e trocam ideias com outros artistas. Oficinas variadas e apresentações artísticas envolvendo poesia, música e teatro integram também

\footnotetext{
${ }^{1}$ Universidade Estadual Vale do Acaraú, Brasil.

${ }^{2}$ Para este artigo, contamos com a valiosa colaboração do professor Francisco Alencar Mota na revisão, a quem agradecemos imensamente.

${ }^{3} \mathrm{O}$ portfólio do Visualidades pode ser visto no site: http://labomevisualidades.wixsite.com/visualidades . $\mathrm{O}$ evento tem um site oficial que pode ser encontrado no endereço: http://www.uvanet.br/hotsite_visualidades/ .
} 
a programação. Além disso, promovemos debates através de conferências com especialistas renomados no país ou do exterior. A comissão organizadora em 2017 foi constituída pelos seguintes professores: Prof. Dr. Nilson Almino de Freitas (UVA); Profa. Dra. Heloisa Buarque de Holanda (UFRJ); Profa. Dra. Ilana Strozenberg (UFRJ); Profa. Dra. Telma Bessa Sales (UVA); Profa. Dra. Alice Fátima Martins (UFG); Profa. M s. Regina Celi Fonseca Raick (UVA); Prof. Ms. José Raymundo Figueiredo Lins Júnior (UVA); Prof. Ms. Philipi Emmanuel Lustosa Bandeira (UNINTA).

A Comissão Científica foi formada pelos seguintes profissionais: $\operatorname{Prof}^{\mathrm{a}}$. $\mathrm{Dr}^{\mathrm{a}}$. Cláudia Turra Magni (UFPEl); Prof ${ }^{a}$. Dr ${ }^{a}$. Clarice Peixoto (UERJ); Prof ${ }^{a}$. Dra ${ }^{a}$ Simone Maldonado (UFPB); Prof. Dr. Alexandre Fleming Câmara Vale (UFC); Prof. Dr. Otávio José Lemos Costa (UECE); Prof. Dr. Everaldo Batista da Costa (UNB); Luiz Antônio Araújo Gonçalves (UVA).

Vale a pena detalhar a história desta atividade e sua inclusão em programa de extensão mais amplo capitaneado pelo Laboratório das Memórias e das Práticas Cotidianas - LABOME, para que possamos pensar duas questões centrais: a restituição e a inserção social.

\section{Histórico das atividades vinculadas ao Visualidades}

O Visualidades é uma atividade de extensão da Universidade Estadual Vale do Acaraú - UVA, que nasce em 2009 a partir das atividades desenvolvidas pelo Laboratório das Memórias e das Práticas Cotidianas - LABOME, vinculado inicialmente ao curso de Ciências Sociais, do Centro de Ciências Humanas - $\mathrm{CCH}-$ da UVA. É uma atividade que passou a ser anual e visa ajudar no incremento do acervo permanente do LABOME - arquivo público de documentos orais e visuais da IES, promovendo a integração entre artes visuais, nas linguagens do documentário, da fotografia, do desenho, da pintura e das instalações, com o acervo permanente relacionado ao patrimônio cultural da cidade no suporte de áudio e vídeo. Portanto, é uma atividade que articula artes visuais e pesquisa. Com o passar dos anos, o Visualidades vem recebendo trabalhos nas linguagens citadas de outras regiões do Brasil e até de outros países, o que obrigou, em 2014 a ser criado uma comissão científica de caráter nacional ${ }^{4}$.

\footnotetext{
${ }^{4}$ A Comissão Organizadora nacional só foi criada em 2017, envolvendo professores da UVA, UNINTA, UFG e UFRJ.
} 
Detalhando a história do evento, vale a pena lembrar que, no primeiro ano, em 2009, o Visualidades foi resultado do esforço conjunto de duas atividades do Curso de Ciências Sociais da Universidade Estadual Vale do Acaraú (UVA): a disciplina de Antropologia Visual e o minicurso de Introdução ao Documentário, ambos ministrados pelos professores Nilson Almino de Freitas e Paulo Passos de Oliveira, respectivamente, ao longo do semestre 2009.2, para os alunos do curso de ciências sociais, envolvendo também discentes do curso de história. Na época foi ofertado também o primeiro curso de Organização de Exposições Visuais, ministrado pela professora Regina Raick. Tiveram como objetivo dar subsídios teórico-metodológicos aos alunos envolvidos, e fomentar a produção de trabalhos que visaram desenvolver a pesquisa com imagem. Imagem, que pode ser usada tanto como recurso metodológico de registro, fonte de investigação como técnica de pesquisa. Foi organizado o I Visualidades, ${ }^{5}$ que consistiu em mostras de trabalhos no campo da fotografia e do documentário, em conjunto com a VIII Semana de Ciências Sociais e com as comemorações pelos 10 anos do Centro de Ciências Humanas, Campus do Junco, nos dias 26 e 27 de novembro de 2009. As mostras foram concentradas no Centro de Ciências Humanas. Foram dez documentários e mostra com seis trabalhos fotográficos de alunos e de professores dos cursos de Ciências Sociais e de História, todos inéditos. Dentre os vídeos apresentados pelos alunos, foram abordados diferentes temas, como transporte universitário, casas de farinha, rezadeiras, o trabalho das bordadeiras, dentre outros. Vale ressaltar que todos os filmes e fotografias abordam elementos relativos à região Noroeste do Ceará, tendo Sobral como foco principal da maioria dos trabalhos.

O Visualidades permitiu, à época, que a comunidade acadêmica da UVA pudesse participar, apresentando propostas de investigações em andamento ou concluídas, que pudessem ter o mesmo objetivo: relacionar pesquisa e imagem. A proposta, com o passar dos anos, fugiu de seu vínculo exclusivo com o Centro de Ciências Humanas e passou a envolver outros cursos. Além dos cursos de Ciências Sociais, Geografia e História, as atividades de formação, bem como o evento envolveram docentes e discentes dos cursos Filosofia, Pedagogia, Administração, Ciências da Computação e Letras. Nesta primeira versão, o público resumiu-se mais aos alunos do Centro de Ciências Humanas e curiosos que souberam do evento, o que totalizava cerca de 100 pessoas ao dia.

\footnotetext{
${ }^{5}$ Veja informações detalhas sobre o Visualidades no site do LABOME, na opção Visualidades e, dentro desta opção, clicar em histórico. O endereço do site é: www.uvanet.br/labome.
} 
Em função do sucesso da atividade de formação e do evento, a equipe responsável pelo Visualidades não interrompeu sua iniciativa. Para tanto, promoveu, em 2010, a criação de uma política de produção de vídeo em formato de documentário com a elaboração do primeiro filme acadêmico realizado com o apoio institucional da UVA: "Sobral no Plural" 6 , idealizado por Nilson Almino de Freitas, roteirizado, dirigido e editado em parceria com Paulo Passos de Oliveira. Sobral no Plural é o primeiro de uma série de documentários que traz ao público o fruto das pesquisas teóricas desenvolvidas e do acervo permanente do Laboratório das Memórias e das Práticas Cotidianas LABOME sobre o patrimônio cultural ${ }^{7}$. O filme visava ser um modelo estético e técnico, apesar de não ser uma produção profissional ainda. $\mathrm{O}$ cuidado com o áudio, a questão do enquadramento, montagem, produção, etc., passaram a ser pensadas a partir desta experiência.

No ano de 2010, a equipe coordenadora esteve dando apoio à produção de novos vídeos e fotografias com alunos da UVA e jovens que participaram dos cursos de Introdução à Fotografia - ministrado pelo prof. Hudson Costa, do curso de Ciências da Computação da UVA - e Introdução ao Documentário - novamente ministrado pelo prof. Paulo Passos de Oliveira -, agora patrocinado pela Secretaria do Desenvolvimento da Cultura de Sobral.

No período de 17 a 30 de novembro de 2010 foi realizado o II Visualidades. O evento teve continuidade na mostra intitulada "Ecos Visuais", promovida pela Secretaria de Desenvolvimento da Cultura de Sobral, entre os dias 16 de dezembro de 2010 e 30 de janeiro de 2011. O II Visualidades ocorreu durante parte da Semana de Ciências Sociais e da Semana de História, sempre nos turnos da noite e da manhã. Nos dias 23 e 24 de novembro foram exibidos, no turno da noite, curtas-metragens. Os mesmos filmes foram exibidos nas manhãs de 24 e 25 , sempre no $\mathrm{CCH}$. O público estimado foi de 100 pessoas por dia, tanto no $\mathrm{CCH}$, quanto na Casa da Cultura. O Visualidades 2010 exibiu 12 videodocumentários e mostras com seis trabalhos fotográficos e duas instalações de alunos e de professores da UVA. Foram temas a população marginal de Sobral, o deslocamento na cidade, o trabalho do cientista social, dentre outros. Nesse evento, o filme "Sobral no Plural" foi apresentado pela primeira

\footnotetext{
${ }^{6}$ Cf.: https://vimeo.com/80116879

${ }^{7} \mathrm{O}$ filme também é repercussão de relatório de Estágio de pós-doutorado em Estudos Culturais, apresentado no início de 2011 no Programa Avançado em Cultura Contemporânea da Universidade Federal do Rio de Janeiro - PACC/UFRJ, desenvolvido pelo articulista que tinha como título "Astúcias da memória: imagens, narrativas de espaço e práticas cotidianas dos moradores da cidade de Sobral/CE". O referido trabalho foi publicado em 2012, com o mesmo título, pela Editora Torre do grupo Multifoco.
} 
vez. Junto a ele, foi feito o lançamento do filme "Cinema Cara Dura", de Alexandre Câmara Vale e Simone Lima ${ }^{8}$, convidados para o evento. O II Visualidades também começa a receber filmes estrangeiros, com o trabalho "Poesia Urbana Catártica" dos diretores peruanos Andrea Venini Falconi e Jimmy Baltazar Palomino?.

Na etapa de 2011 do programa, boa parte do acervo permanente do Labome, documentado em suporte audiovisual, foi usado como material bruto para novos vídeos relacionados à história oral e à percepção socioespacial da cidade. Além disso, através do Centro de Ciências Humanas, foi publicado, no final de junho de 2011, edital de seleção de projetos a serem realizados que foram acompanhados pela equipe, visando dar uma qualidade mais profissional às obras produzidas, os quais foram apresentados em novembro, no III Visualidades. Dois cursos foram ofertados: Introdução ao Documentário, realizado na Faculdade Luciano Feijão, parceira no evento, e curso de Organização de Exposições Visuais pela UVA. Em outubro foi aberto novo edital para obras prontas. Ao todo, foram exibidos 17 filmes de curta metragem, três exposições fotográficas, três projetos de artes plásticas e uma instalação. Dentre os filmes, sete foram de convidados como Rosemberg Cariry, Petrus Cariry, Bárbara Cariry e Luis Saraiva (Portugal).

Para o evento de $2012^{10}$, a UVA contou com apoio do programa "Visualidades: identificação e registro audiovisual para preservação do patrimônio cultural da cidade de Sobral/CE", aprovado no edital interministerial PROEXT/2011, capitaneado pelo Ministério da Educação. A proposta pretendia trabalhar com o tema do patrimônio histórico na cidade de Sobral. Ao todo foram seis projetos vinculados, envolvendo disciplinas, professores e alunos (16 bolsistas) dos cursos de História, Ciências Sociais e Geografia da UVA. Os projetos pretendiam trabalhar com as memórias dos moradores dos bairros periféricos, memória da educação, mundos do trabalho, patrimônio imaterial, particularmente as celebrações religiosas, patrimônio material, explorando a memória afetiva dos moradores de Sobral relativa às edificações do sítio histórico tombado e paisagens urbanas. Nesse ano, o Visualidades também contou com o apoio do Programa de Apoio a Eventos no País, da Coordenação de Aperfeiçoamento de Pessoal de Nível Superior - PAEP/CAPES. A parceria com a Secretaria de Educação de Sobral, oferecendo curso de Introdução ao Documentário para o programa Jornada

\footnotetext{
${ }^{8}$ Cf.: https://www.youtube.com/watch?v=7FFn8ii6b0M

${ }^{9} \mathrm{Cf}$.: https://www.youtube.com/watch?v=zxsunaraHEQ

${ }^{10}$ A cobertura do evento está no endereço: https://vimeo.com/76009604
} 
Ampliada, permitiu a inclusão de obras produzidas por alunos do ensino fundamental da rede pública na mostra. Neste ano (2017), foram 24 filmes de vários estados do Brasil, que foram exibidos junto com os produzidos pelos alunos dos cursos de Sobral. Foram 7 trabalhos de fotografias, 3 de pintura e 4 instalações. Os cursos de Produção de Documentários, sendo duas turmas, uma pela UVA e outra pelo Programa Jornada Ampliada da Prefeitura de Sobral, e o curso de Sensibilização Visual oferecido também pela UVA, ajudaram na produção de parte deste acervo apresentado.

A primeira semana, entre 26 a 30 de novembro de 2012, consistiu em apresentação dos documentários nas escolas, no Centro de Referência da Assistência Social - CRAS dos bairros selecionados, na Escola de Cultura, Comunicação, Ofícios e Artes - ECOA, Casa da Cultura de Sobral e Centro de Ciências Humanas da UVA. Ao todo foram duas semanas de evento. Em parceria com o Programa Institucional de Bolsa de Iniciação a Docência dos Cursos de Ciências Sociais e História da UVA, 4 escolas públicas de Sobral, além do CRAS do bairro Vila União, foram focos das exibições dos filmes, envolvendo o público presente nas discussões com os diretores, lugares esses que abrigam os moradores mais pobres da cidade. Neste ano (2017), o evento ganha contornos de itinerância, abrangendo vários equipamentos públicos e privados como locais de exposição e mostras de filmes.

Durante a segunda semana, entre 3 e 7 de dezembro de 2012, promoveu-se atividades acadêmicas como conferências, mesas-redondas e mini-cursos. As atividades acadêmicas aconteceram no Centro de Ciências Humanas da UVA e na Escola de Comunicação, Ofícios e Artes de Sobral - ECOA. Dia três de dezembro houve o lançamento do filme "O Voo da Beleza", do professor Alexandre Fleming (UFC) no Auditório Milton Santos do Centro de Ciências Humanas da UVA. No mesmo local, entre os dias três e cinco de dezembro, à tarde, o professor Etienne Samain (UNICAMP) ministrou mini-curso "Multimídia, criatividade e pesquisa". No dia quatro, o mesmo professor proferiu conferência "A matriz sensorial do pensamento humano e as artes enquanto epicentro das culturas humanas" ", na ECOA. Os professores Roberto Novaes (UFRJ) e Alexandre Fleming (UFC), participaram da mesa redonda "Educação e Audiovisual", no dia quatro de dezembro, na ECOA.

No ano de $2013^{12}$, a vigência do programa aprovado no edital PROEXT 2011 foi renovado, tendo sido, como decorrência, comprados novos equipamentos, através do

\footnotetext{
${ }^{11}$ Cf.: https://www.youtube.com/watch?v=rcz2iYzTVRo

${ }^{12}$ A cobertura do V Visualidades está no endereço: https://vimeo.com/111774813
} 
projeto "Memórias, Bairros e Cidades Possíveis: narrativas e imagens", aprovado no edital de humanidades do CNPq (MCTI/CNPq/MEC/CAPES $n^{\circ}$ 18/2012), e diversificado o número de parceiros envolvidos. O SESC/Sobral ofereceu o curso de roteiro e produção de documentários; a Universidade Federal do Ceará, através da Secretaria de Cultura Artística, ofertou curso de captação de áudio e produção de trilha sonora e a Escola de Comunicação, Ofícios e Artes de Sobral da Prefeitura Municipal de Sobral ofereceu uma série de oficinas, seminários e atividades livres, para formação nas linguagens do desenho, da pintura e das instalações, através do programa "Atelier livre", coordenado pela professora Regina Raick (UVA).

A parte acadêmica do evento foi promovida em maio de 2013. Dia 22 de maio organizamos o I Fórum de Artes Visuais com produtores locais. Foi constituída uma comissão executiva e debatido alguns desafios e soluções para o campo da produção das artes visuais. Um documento sobre as deliberações do Fórum foi sistematizado e amplamente divulgado, tratando dos temas debatidos. No dia 23 de maio, a professora Clarice Peixoto (UERJ) ministrou a conferência "A foto no Filme de Acervos Fotográficos no Vídeo Portrait" ${ }^{13}$ no auditório Milton Santos, do CCH da UVA. Dia 24 de maio foi lançada a primeira publicação do grupo de professores e alunos que compõem o Visualidades, em DVD-rom, com artigos, fotos e filmes com o título "Visualidades: pesquisas e artes em extensão", pelas Edições UVA. No mesmo dia, a professora Clarice Pixoto (UERJ) lança DVD-rom: "Imagens e narrativas" (Grupo de Pesquisa INARRA/UERJ).

Em setembro de 2013, foi lançado edital para seleção das obras a serem expostas no IV Visualidades que aconteceu no final do mês de outubro. Foram 21 filmes apresentados, somando aos produzidos pelos cursos de formação e os demais enviados por produtores de vários estados do país. As exposições contaram com 7 trabalhos de fotografia, 2 de pinturas, 1 desenho e 1 instalação. Houve ampliação da quantidade de espaços e equipamentos usados para exibição dos filmes. Ao todo foram 13 lugares diferentes, envolvendo escolas públicas, Centros Sociais Urbanos e CRAS de três cidades da região, além de Sobral.

No evento de 2014, ${ }^{14}$ chegamos a incluir como espaço de exibição, 24 lugares nas cidades de Sobral, Groaíras, Meruóca, Forquilha e Ipú. Os parceiros foram o SESC, ECOA/Sobral, Prefeitura de Sobral, Prefeitura de Meruóca, Secretaria de Cultura de

\footnotetext{
${ }^{13}$ Cf.: https://www.youtube.com/watch?v=964WfiBE9Os

${ }^{14}$ A cobertura do VI Visualidades está no endereço: https://vimeo.com/148088370
} 
Forquilha, Curso de Audiovisual do Liceu de Sobral e a ONG Universo Audiovisual. Mais uma vez tivemos o apoio do programa PAEP/CAPES e projetos já citados do PROEXT e do Edital de Humanidades do CNPq. Tivemos uma participação especial do Laboratório de Imagem e Som do Departamento de Antropologia da Universidade de São Paulo - LISA/USP que enviou 12 filmes para serem apresentados. Ao todo, foram 27 filmes apresentados, 10 trabalhos com fotografias, um de desenho e três instalações. Mais uma vez o evento foi dividido em duas partes. A primeira foi realizada entre os dias 5 e 8 de maio de 2014, com exposição fotográfica do professor Doutor Rubens Elias da Silva da UFPB, com o título "O bote e a rede: sociabilidades costeiras através de imagens", sendo apresentada por sua curadora, a professora Doutora Simone Maldonado (UFPB), no auditório Milton Santos, no CCH da UVA. Ocorreu também dois seminários: "Invisibilidades Simbólicas na Paisagem Rural de Icó", com o professor Doutor Otávio José Lemos Costa (UECE) e "Tempos dos Sem-Voz: produção fílmica e cidadania na França das minorias", com a professora Doutora Cláudia Turra Magni (UFPel). A segunda parte aconteceu entre 3 e 7 de novembro em vários locais das cidades já citadas. Entretanto, tentamos também incluir mais duas conferências: “Artes Visuais e Artes do Vídeo: outros fazedores" ${ }^{15}$ com a professora Doutora Alice Fátima Martins (UFG) e "Experiências e memórias: um relato" com o ator Chico Expedito. Incluímos neste ano uma experiência inédita de inserção dos produtores sem formação acadêmica em cinema na nossa programação, objetivando uma troca de vivências com a linguagem do audiovisual. O Visualidades deseja fazer com que estes produtores possam se integrar às atividades previstas e dialogar com o meio acadêmico mostrando suas experiências. Iniciamos com o grupo Cinecordel ${ }^{16}$, da cidade de Forquilha que teve um de seus trabalhos incluídos na mostra e participaram ativamente do evento, assim como foram tema de uma das conferências com a professora Dra. Alice Martins já citada.

Neste ano de 2014, formamos uma comissão científica nacional com os seguintes professores: Profa. Dra.Cláudia Turra Magni (UFPel), Profa. Dra. Clarice Peixoto (UERJ), Profa. Dra. Simone Maldonado (UFPB), Profa. Dra. Ilana Strozenberg (UFRJ), Prof. Dr.Alexandre Fleming Câmara Vale (UFC), Prof. Dr. Otávio José Lemos Costa (UECE) e Profa. Dra. Alice Fátima Martins (UFG). Estes professores foram mantidos na Comissão Científica de 2015, acrescida do Prof. Dr. Everaldo Batista da

\footnotetext{
${ }^{15}$ Cf.: https://www.youtube.com/watch?v=RbDf5JnYJi8

${ }^{16}$ Sobre este movimento, conferir o endereço: http://cinecordel.blogspot.com.br/
} 


\section{Costa (UNB).}

No Visualidades do ano de $2015^{17}$, recebemos 31 documentários, 13 conjuntos de fotografias para exposição e duas instalações. Os trabalhos vieram de vários locais do Brasil. Houve trabalhos do Peru e Argentina também na programação. Neste ano, recebemos as obras do Prêmio Pierre Verger, da Associação Brasileira da Antropologia, que enviou 13 filmes e cinco exposições fotográficas. Dos 31 filmes, dez são resultantes do Curso de Realização de Documentários apoiado pelo SESC/Sobral e programa "Visualidades: identificação e registro audiovisual para preservação do patrimônio cultural da cidade de Sobral/CE" financiado pelo edital PROEXT/MEC/2011. Esta versão do evento também teve apoio da Fundação Cearense de Apoio ao Desenvolvimento Científico e Tecnológico - FUNCAP, fundação de amparo do Estado do Ceará, e do programa PAEP/CAPES. O atraso do repassa da CAPES acabou provocando a divisão das atividades em dois momentos.

Primeiramente, entre 16 e 20 de novembro, organizamos as mostras de filmes e exposições que ocuparam 29 lugares nas cidades de Sobral, Meruóca, Forquilha, Acaraú, Reriutaba e Graça. O agendamento das mostras foi feito pelo programa Programa Institucional de Bolsas de Iniciação à Docência - PIBID, dos cursos de Ciências Sociais, História e Letras da UVA, além do programa Programa de Educação Tutorial - PET também do curso de História da UVA. O público estimado para esta versão do evento foi de 1.500 pessoas. Para este primeiro momento, tivemos também o lançamento dos filmes produzidos pelo projeto de audiovisual "Poéticas do Poço: etnografias e imagéticas compartilhadas", com Prof. Dr. Alexandre Fleming Câmara Vale (UFC) e sua equipe, no dia 16 de novembro no auditório Milton Santos, da UVA; a conferência "Paisagens Vernaculares na Meruoca", pelo professor Otávio Lemos (UECE), no dia 19 de novembro, também no $\mathrm{CCH}$. As parcerias interinstitucionais foram fatores positivos. Os parceiros foram: SESC/Sobral; Escola de Cultura, Comunicação, Ofícios e Artes de Sobral - ECOA; Prefeitura de Sobral; Mestrado Acadêmico em Geografia - UVA; Associação Brasileira de Antropologia - ABA; CAPES; FUNCAP; Embaixada da França no Brasil (financiadora do Prêmio Pierre Verger); Prêmio Pierre Verger (ABA); Comitê de Antropologia Visual da ABA. A comissão científica do evento foi ativa na divulgação e articulação para envio de trabalhos, representando as seguintes universidades: UFRJ, UERJ, UFPB, UNB, UFC,

\footnotetext{
${ }^{17}$ A cobertura do evento pode ser vista no site: https://www.youtube.com/watch?v=OzW30xWkCEQ
} 


\section{UFPEl, UFG e UECE.}

A segunda parte do VII Visualidades aconteceu entre 11 e 15 de abril. De destaque mencionamos: a oficina "Explorando a Imaginação Etnográfica: alguns apontamentos sobre arte e o fazer antropológico", dividida em três momentos, nos dias 11 e 12 de abril, totalizando 15 horas/aulas, no $\mathrm{CCH}$, coordenada pelo Prof. Dr.Vitor Pinheiro Grunvald (USP). Igualmente, no mesmo local, no dia 13 de abril, o seminário "Artes Visuais e Geografia: a paisagem como instrumento de investigação", pelo Prof. Dr. Caio Amorin Maciel (UFPE), tendo como debatedor o Prof. Dr. Otávio Lemos (UECE), componente da comissão científica.

Em 2016, em função da crise política do país, tivemos alguns problemas com nossos parceiros convencionais, a despeito do que conseguimos, ainda, realizar o VIII Visualidades ${ }^{18}$. Prevíamos até a possibilidade de tornar o evento bianual em função da série de atividades acumuladas e da falta de financiamento. Os próprios filmes idealizados nos cursos de realização do ano anterior, avaliávamos que precisariam mais tempo para suas produções, especialmente aqueles de cunho mais etnográfico. O curso de Realização de Documentários, em 2016, não foi ofertado em função da falta de apoio. Entretanto, muitos projetos ainda estavam em andamento, pelo menos uns sete, apesar de somente um ter sido finalizado para ser apresentado nesta versão do evento.

Com recursos próprios, ainda conseguimos realizar o evento entre 5 e 7 de dezembro de 2016. A mostra descentralizada aconteceu em 21 lugares nas cidades de Sobral, Ipú, Cariré, Viçosa do Ceará, Pacujá, Graça, Ibiapina, Moraújo, Marco e Hidrolândia. Em 2016, assim como aconteceu em 2015, o VIII Visualidades contou com a parceria da Associação Brasileira de Antropologia - ABA, que enviou obras visuais não exibidas ainda no Visualidades, da mostra itinerante do Prêmio Pierre Verger. Ao todo, foram exibidos 17 filmes e 17 exposições das demais linguagens. O público estimado foi de cerca de 1500 pessoas.

$\mathrm{Na}$ programação acadêmica, foram oito oficinas ofertadas com professores locais:

- Oficina de Fotografia: Foco pelas narrativas dos estudantes da periferia pela cidade.

Ministrante: Maiara Maria de Araújo (UVA)

Local: Escola Estadual Deputado Manoel Rodrigues - Viçosa do Ceará 18 A cobertura do evento pode ser vista no endereço: https://www.youtube.com/watch ?v=Wbyesfff6
$34 \& \mathrm{t}=32 \mathrm{~s}$ 
Data: 06.12.

- Oficina: "No mundo doido da arte contemporânea"

Ministrante: Ana Cecília Araújo Soares de Sousa (INTA)

Local: Faculdades INTA (Coordenação do Curso de Jornalismo)

Data: 07.12

- Oficina: Produção audiovisual indígena no Ceará

Ministrante: Philipi Bandeira (INTA)

Local: Faculdades INTA (coordenação do Curso de Jornalismo)

Data: dia 06.12.

- Oficina: Fanzine

Ministrante: Liana Cristina Villar Dodt (INTA)

Local: Faculdades INTA (Coordenação do Curso de Jornalismo)

Data: 07.12.

- Audiovisual: História do cinema e pré-produção.

Ministrante: José Lins Jr. (UVA)

Local: Centro de Ciências Humanas - CCH.

Data: 05 a 07/12.

- Fotografia: sensibilização visual de moradores da periferia de Sobral

Ministrante: Regina Raick, Joicilene Ramos, Bruna Araújo (UVA)

Local: Loja Quebrada Roots - Bairro Terrenos Novos

Data: 05 e 06/12.

- Oficina de conservação de acervos

Ministrantes: Edcarlos da S. Araújo, Jaiana Kelly R. Alcântara, Adelina L. Guimarães, Ma.Malena P. Mesquita (PET/História/UVA)

Local: CCH/NEDHIS

Data: 05 e 06/12.

- Oficina de catalogação de documentos

Ministrantes: Fco. Adriano M. Gonçalves, Isabela A. Brito, Ma. Deiziane Lino (PET/História/UVA)

Local: CCH/NEDHIS

Data: 06 e 07/12. 
Além das oficinas, dia 5 de dezembro lançamos a segunda publicação em DVDrom da equipe do Visualidades, com o título "Outros Sentidos e Visualidades", e a conferência "Etnografias Audiovisuais Participativas", a cargo do Prof. Dr. José Maria Gonçalves da Silva Ribeiro (professor da Universidade Aberta de Lisboa e Professor Visitante na Faculdade de Artes Visuais da Universidade Federal de Goiás) ${ }^{19}$, no auditório Milton Santos, do CCH. No Dia 6 de dezembro de 2016, tivemos a abertura das exposições de artes visuais e roda de conversa sobre Antropologia Visual no Ceará com Ewelter Rocha (UECE), Nilson Almino (UVA), Philipi Bandeira (INTA) e José Lins (UVA), na ECOA.

O IX Visualidades, realizado em 2017, assim como a versão do ano anterior, não teve apoio dos órgãos de fomento acadêmicos. Esta dificuldade renova as já enfrentadas pelo país no que se refere ao apoio à cultura e a produção acadêmica. Fizemos uma campanha aberta no site do Catarse ${ }^{20}$, mas, a maior parte dos recursos adquiridos vieram do Instituto de Apoio e Desenvolvimento da UVA - IADE, organização social que já vinha apoiando o LABOME com o pagamento de uma funcionária desde 2003, mas que se prontificou, no ano de 2017, além disso, a financiar diretamente o evento, e da ECOA, através de edital de ocupação cultural da cidade. Muitos doadores individuais preferiram fazer seus repasses diretos para a coordenação do evento, dispensando o instrumento de financiamento coletivo que adotamos, o que consistiu em ajuda indispensável. Neste ano, também não foi ofertado cursos de formação no campo do audiovisual, o que não consistiu em parada nos projetos em andamento. Pelo contrário, o LABOME apoiou diretamente cinco filmes apresentados ${ }^{21}$. Ao todo, foram 39 filmes enviados via edital de seleção lançado em setembro e 14 trabalhos nas demais linguagens. Os trabalhos enviados vieram de Alagoas, Rio de Janeiro, São Paulo, Rio Grande do Sul, Maranhão, Pará, Paraná, Mato Grosso, Paraíba, Ceará, Tocantins, Distrito Federal (Brasília), Minas Gerais, Alagoas e Bahia, além de alguns que vieram dos EUA, Paraguai, Uruguai, Portugal, Suíça, Japão e Colômbia.

A Comissão Organizadora foi ampliada, e composta por representantes de cinco universidades brasileiras. São os professores já citados no começo do artigo, a saber: Prof. Dr. Nilson Almino de Freitas (UVA), Profa. Dra. Heloisa Buarque de Holanda

\footnotetext{
${ }^{19}$ Cf.: https://www.youtube.com/watch?v=le4-Cf7V4gQ

${ }^{20}$ Veja campanha no site: https://www.catarse.me/ix_visualidades_8c20

${ }^{21}$ Alguns teasers e trabalhos que estão sendo desenvolvidos pelos LABOME podem ser vistos nas redes sociais nos sites: https://www.facebook.com/LABOMEUVA/?ref=bookmarks ou https://www.facebook.com/Visualidades/?ref=bookmarks .
} 
(UFRJ), Profa. Dra. Ilana Strozenberg (UFRJ), Profa. Dra. Telma Bessa Sales (UVA), Profa. Dra. Alice Fátima Martins (UFG), Profa. Ms. Regina Celi Fonseca Raick (UVA), Prof. Ms. José Raymundo Figueiredo Lins Júnior (UVA) e Prof. Ms. Philipi Emmanuel Lustosa Bandeira (UNINTA). Alguns destes professores faziam parte da Comissão Científica que ficou com a seguinte composição, também já citada: Profa ${ }^{a}$ Dr ${ }^{a}$. Cláudia Turra Magni (UFPEl), Prof ${ }^{a}$. Dr ${ }^{\mathrm{a}}$. Clarice Peixoto (UERJ), Prof ${ }^{\mathrm{a}}$. Dr ${ }^{\mathrm{a}}$. Simone Maldonado (UFPB), Prof. Dr. Alexandre Fleming Câmara Vale (UFC), Prof. Dr. Otávio José Lemos Costa (UECE), Prof. Dr.Everaldo Batista da Costa (UNB), Luiz Antônio Araújo Gonçalves (UVA).

As mostras descentralizadas, com ajuda do agendamento feito por estudantes da UVA e bolsistas do programa PIBID dos cursos de Ciências Sociais, História e Letras, aconteceram em 35 lugares, em 13 cidades: Sobral, Varjota, Graça, Ibiapina, Forquilha, Viçosa, Moraújo, Coreaú, Acaraú, Hidrolândia, Ubajara, Miraíma e Rio de Janeiro. No Rio de Janeiro, o IX Visualidades está sendo organizado pelo Programa Avançado de Cultura Contemporânea da UFRJ.

Na programação, abrimos oficialmente o evento no dia 5 de dezembro, com a conferência “Antropologia Com Imagens, Etnografias de Rua e Coleções Etnográficas”, proferida por Cornélia Eckert (UFRGS), no Auditório Milton Santos do CCH/UVA ${ }^{22}$. No dia 6 de dezembro, ocorreu a Conferência: "Etnografias audiovisuais de comunidades tradicionais", com Marco Antônio Gonçalves (UFRJ), no auditório Milton Santos no CCH/UVA. Os dois professores conferencistas também ministraram oficinas. A professora Cornélia Eckert ofertou oficina no dia 5, à tarde, no Memorial da Educação Superior de Sobral - MESS, com o título “Antropologia Com Imagens: A experiência na antropologia visual e do BIEV". No dia 6, no mesmo local e horário, o Professor Marcos Gonçalves ofertou oficina com título "Cinema, Artes Visuais e Antropologia”. Em Viçosa do Ceará, também dia 6, à tarde e dia 7, foi ministrada a oficina "Fotografia: A escola que eu queria", por Maiara Maria de Araújo, na Escola Antonio Ângelo dos Santos. No dia 6 pela manhã, no MESS, ocorreu a oficina de fotografia, ministrada por Alex Costa.

Neste ano, também retomamos a ideia da consolidação do Fórum de Artes Visuais que estava estagnada, mas, que agora, foi retomada por um coletivo de jovens de Sobral. Aproveitamos a presença dos professores Marcos Gonçalves e Cornélia

\footnotetext{
${ }^{22}$ Conferir transmissão ao vivo gravada no site: https://www.youtube.com/watch?v=pv-KmUXfYBk .
} 
Eckert para promovermos encontros com este coletivo. A ideia é que os jovens pudessem expor seus trabalhos e, a partir da apreciação artística, pudesse haver um diálogo entre arte e antropologia visual.

Toda esta descrição de atividades precisa ser situada em uma reflexão conceitual que entendemos ser importante. Vale a pena elencarmos algumas questões agora.

\section{Visualidades: questões teóricas norteadores}

Uma das questões que se apresentam com força na realização do Visualidades tem relação com um compromisso social de restituição. Rial (2016) chama à atenção que este conceito de restituição não é novo no campo da Antropologia, e é sempre lembrado na proposta metodológica da pesquisa compartilhada, herdeira, especialmente dos trabalhos de Robert Flaherty e Jean Rouch. O primeiro ficou famoso com seu trabalho Nanook of the North. Entretanto, apesar de toda a produção e roteiro ser compartilhado com os Inuit, estes últimos pouco ganharam financeiramente com a obra, enquanto seu diretor colhe os frutos de seus ganhos. Já no caso de Rouch, os ganhos financeiros foram distribuídos em sociedade com seus interlocutores, o que apresenta um diferencial na discussão clássica que faz oposição entre o "eu" e o "outro" no campo da Antropologia. A proposta é que a relação pudesse ser colocada de outra forma. A relação seria "eu" e "tu". Apesar da simetria econômica, política e moral, ainda não ser plena e completa, a oposição entre "sujeito" e "objetivo" passa a ser revista. O "objeto" passa a ser agente ou sujeito, pelo menos na produção e roteiro das obras.

Entretanto, para Rial (2016), a restituição teria de fato, dois sentidos: devolver as imagens e divulgar os resultados da pesquisa. Estes sentidos podem ser associados, segundo a autora, à ideia de extensão, atividade esta ainda pouco valorizada pelas instituições acadêmicas que avaliam os trabalhos dos pesquisadores. Se valoriza muito mais a pesquisa na sua versão textual do que a extensão.

No caso do Visualidades, o grupo que vem organizando suas atividades, vai um pouco na contramão desta tendência. A restituição e a extensão são o foco central, relacionados diretamente a formação de "público" e incentivo à reflexividade. Não necessariamente aquela que tem como finalidade influenciar agentes públicos diversificados, legislações e políticas públicas. A ideia é sair dos muros da universidade. Não mais chamar as pessoas para ver os resultados dos trabalhos desenvolvidos, mas ir até as pessoas, especialmente aquelas que não têm acesso aos saberes produzidos na 
universidade, onde, muitas delas são obras produzidas de forma compartilhada com os pesquisados, como as que são produzidas pelo LABOME, por exemplo, assim como muitas outras que são mostradas no evento. Mesmo não tendo uma orientação definida no edital no que concerne ao conceito da obra a ser apresentada, muitas são produções compartilhadas com os grupos que são foco da arte visual pronta.

Logicamente que a obra pronta não é interpretada pelo público da mesma forma como entende a comunidade acadêmica. A restituição, portanto, não tem a simetria na leitura da obra pronta, se comparada ao que o pesquisador quis definir, o seu conceito, e a concepção dos interlocutores envolvidos como pesquisados, ou o público que assiste, mesmo que estes últimos tenham vivido experiências compartilhadas na produção, como afirma Rial (2016) ${ }^{23}$. Pensando nisso, no caso do Visualidades, tentamos levar a equipe de produção e, na medida do possível, os personagens, juntarem-se com o público para, após a exibição, ambos possam dialogar e refletir juntos sobre a obra final.

Só a título de exemplo, pelo LABOME produzimos o filme "Rap nas Quebradas". A direção foi realizada por bolsista de iniciação científica ${ }^{24}$. A proposta foi escolher artistas locais que usam o Rap como forma de crítica social e valorização da periferia. Chegamos a convidar um artista local para compartilhar a direção, mas em função de suas necessidades familiares e profissionais, a efetivação desta participação acabou não acontecendo.

A pesquisa sobre com os rappers não estava sendo possível pela lógica tradicional do trabalho de campo que se convencionou batizar de observação participante. Eles não apresentavam interesse algum na proposta de serem "divulgados" via texto acadêmico. Quando entramos em campo com os equipamentos de filmagem, foi diferente. Os artistas envolvidos são engajados em movimentos de jovens que visam superar problemas sociais decorrentes da pobreza e condições de sobrevivência precárias na periferia. Já estão próximos do audiovisual, especialmente por produzirem clipes para divulgação de suas músicas no Youtube ${ }^{25}$. Acharam que o filme poderia

\footnotetext{
${ }^{23}$ Em conferência Mme. Françoise Zonabend, realizada em janeiro de 2014, na Maison des Sciences de l'Homme da Université de Bourgogne (Dijon, França), durante o colóquio internacional Etnografias Plurais IV: Restituição e Difusão de Dados de Pesquisa, organizado pela Société d'Ethnologie Français (https://vimeo.com/114780326), a etnóloga chama atenção dos problemas da restituição no mesmo sentido de Rial (2016). No texto de Vale (2014), a restituição também é problematizada em sentido semelhante.

${ }^{24}$ Ana Kélia de Sousa Viana, bolsista do programa PIBIC/CNPq/UVA do projeto "Bairros da cidade e memória: percepção espacial, imagem e histórias da cidade de Sobral/CE contada por seus moradores".

${ }^{25}$ Uma das cenas do filme mostra a produção de clipe por parte dos Rappers. O Teaser do filme pode ser visto no site: https://www.youtube.com/watch?v=ipsojkYbuX8.
} 
ajudar no objetivo de ressaltar seus compromissos com a transformação da sociedade que vivem, especialmente da periferia. Percebemos os interesses comuns, e o diálogo começou a fluir. As cenas foram pensadas em conjunto com os artistas e eles compartilharam experiências conosco, mesmo que a coautoria não tenha sido consolidada. O filme foi produzido sem um roteiro definido. Cada dia, quando íamos a campo, não sabíamos muito bem o que fazer. Sempre descobríamos quando estávamos lá. $\mathrm{Na}$ montagem do documentário é que fomos descobrindo o que fazer e, mesmo assim, sem muita chance de corrigir possíveis erros de gravação. Mesmo assim, alguns deles ainda foram corrigimos.

O que pretendemos destacar aqui foi o que aconteceu no dia da exibição do filme no IX Visualidades. Convidamos os artistas e dois deles compareceram. Os demais enviaram mensagens justificando suas ausências, e combinaram outro momento para exibição ou fizeram comentários positivos sobre a obra. No dia 7 de dezembro, um dos dias de exibição, no momento do debate, convidamos eles para falarem. Para nossa grata surpresa, falaram com propriedade e fundamentação sobre a obra, chamando atenção para sua participação, o que foi também afirmada pela diretora do filme. Neste caso, houve uma simetria entre o produtor e os personagens, ao menos no momento do debate. Estes últimos falaram sobre o poder de decisão nas suas ações na produção do filme, compartilharam sentimento de que estavam representados pela obra. Pelo que afirmaram, se viram no filme. Claro que a simetria acaba ali, já que o reconhecimento social da circulação do filme após aquele momento não vai ser realizado para o diretor da mesma forma que o direcionado ao "personagem". Entretanto, este reconhecimento para o diretor não seria propriamente financeiro; pelo menos não diretamente, já que o filme produzido pelo LABOME não tem a finalidade de ser vendido. Neste caso, a restituição não provoca realmente resultados simétricos para produtor e "personagem". Mesmo que as repercussões não sejam financeiras, o diretor procura entrar no campo de circulação de obras de sua área visando reconhecimento no seu campo de atuação. Já o personagem frequenta outra arena político-cultural. No último caso, o filme pode ajudar nesta busca de ser conhecido no seu círculo de experiências, mas inserido em regras diferentes e o personagem seria mais um, dentre outros, no documentário. A busca pela consagração, no caso do personagem, seria "disputada" dentre os demais que aparecem no filme. Isso depende muito da forma como cada um se apropria da obra que estará disponível na internet. 
Este tipo de experiência de simetria promovida pelo debate após a exibição pode ser extrapolada e vista através de outras perspectivas. Como o evento ocorre nas escolas de ensino fundamental e médio, ONG's e espaços situados na periferia, a curadoria procura fazer uma programação que tenha relação com as formas de sociabilidade e valores do meio cultural vivido pelas pessoas que dela vão participar. Falar de periferia, por exemplo, acaba sendo importante critério para a escolha de um filme que vai ser exibido nesta espacialidade. Foi comum, em diferentes versões do evento, ouvirmos depoimentos de alunos afirmando a identificação com o tema do filme, falando sobre a proximidade que existe entre o que viram e o que vivem. Sempre que possível, pedimos aos diretores para estarem presentes, promovendo o diálogo entre o público que assiste e os produtores. Logicamente que nem todos se identificam com o que é mostrado, já que os grupos que assistem não são totalmente homogêneos, assim como muitos filmes são trocados no momento da exibição, problemas técnicos acontecem e, em muitos casos, a equipe que produziu não está presente, cabendo aos monitores voluntários promoverem o debate. Mas o momento do debate após a exibição mostra esta tendência de promover a reflexividade necessária para se pensar a vida em sociedade.

A experiência do evento também mostra outra variável importante que merece ser citada, sem esquecer a restituição que é central: a linguagem. Gonçalves (2009) chama atenção que, desde a década de 1980 a antropologia vem passando por uma reviravolta crítica no que se refere a ideia de representação do "outro". A pesquisa passa a ser questionada no que se refere a sua arena política-cultural de produção. A produção etnográfica passa a ser entendida como uma construção compartilhada que leva em conta vozes diferentes do "seu dono", salientando a polifonia, o dialogismo, a alegoria, a ficção e a interpretação, mesmo que o autor não reconheça as demais vozes e se aproprie delas para dizer que a dele tem uma autoridade maior, colocando-a como próxima da palavra verdadeira. A imagem técnica vem acompanhando esta tendência de revisão de sua definição. Não é um "retrato" da realidade, mas um desenho de ideias persuasivas que visam construir uma verdade parcial que visa criar no leitor uma impressão de realidade. Neste caso, a imagem do filme e das artes visuais passam a ser estímulos para a imaginação criativa de novas possibilidades de se pensar o mundo através de um produto híbrido que cruza experiências antropológicas, artísticas e documentais, com várias repercussões estéticas. O momento do debate faz com que os filmes possam não ser exclusivamente formadores de plateia passiva, mas possa ser 
momento de troca de proposições, aprendizado, provocações e partilhas de afetos e saberes.

Por outro lado, vivemos em um momento em que a imagem invade todos os espaços. A proliferação de autorrepresentações e apropriações da linguagem da imagem técnica deixa de ser feita somente por especialistas. Neste caso, a formação de público ou plateia também pode ser revisto por outro prisma. De fato, a linguagem já está sob o domínio daqueles que os assistem, pelo menos no seu aspecto de leitura de obra pronta. Nem todos dominam as discussões sobre o processo de produção. Muitos ainda entendem o documentário como expressão de experiências factuais. Muitos, ainda, esquecem das nuances da montagem, da performance e da misancene, próprias do documentário. Entretanto, a imagem técnica já faz parte das vivências de pessoas de diferentes classes sociais.

Como lembra Fonseca (1995), o vídeo tem um enorme leque de consumidores. Com as novas tecnologias de smartphones, aparelhos de DVD (que parece fadado ao desuso), computadores, dentre outros aparelhos, é cada dia mais fácil o acesso ao vídeo. Não só aquele produzido pelas produtoras profissionais e canais de TV, mas também aqueles considerados "caseiros" ou "amadores". No caso do documentário, seja ele produzido no campo da Antropologia, seja ele produzido por profissionais de outras áreas, com diferentes estéticas, métodos e finalidades, acabam ganhando uma capacidade de circulação que a linguagem escrita não comporta. Especialmente quando os personagens em cena não são atores profissionais e estão muito próximos daqueles que os assistem no sentido de uma ética, moral e capital cultural. É comum, nas diferentes versões do evento, as pessoas que assistem pedirem cópias dos filmes. As demais artes visuais, não são tão solicitadas em função da sua pouca circulação, pois a logística da exposição limita a mobilidade. Mas, mesmo assim, parecem ter uma adesão muito mais efetiva do que a escrita em grupos sociais que vivem "após os muros" da academia.

Com o vídeo, a própria pesquisa passa a ser valorizada e o pesquisador ganha um lugar mais prestigioso em função da cobiça das pessoas em aparecerem na imagem. A circulação dos filmes, como acontece em todos os anos, acaba não se restringindo a eventos acadêmicos. É comum coletivos, ONG's, escolas, dentre outras instituições e grupos, procurarem o LABOME com o objetivo de divulgar os filmes produzidos em exibições públicas que promovem. O próprio acervo do LABOME é enriquecido com novos documentos visuais que podem ser usados para outras obras ou como fonte de 
pesquisa. É este aspecto da relação entre acervo, produção e divulgação de artes visuais que pretende-se discutir agora.

\section{Considerações finais: acervo e artes visuais}

O LABOME foi criado em 2003, com a finalidade de criar um banco de dados de acervos documentais especiais permanentes, especialmente com áudio, vídeo e fotografia. Pesquisas relacionadas ao patrimônio cultural foram as primeiras a serem desenvolvidas, sendo renovadas pelos anos seguintes, consistindo em 2017 ainda o foco central dos pesquisadores envolvidos. Apesar disso, outros temas foram sendo incluídos e novos projetos apoiados. A ideia é simples: o pesquisador cadastra seu projeto via sistema LABOME; se ele for aprovado, apoiamos com equipamentos de áudio, fotografia e vídeo. O acervo produzido deve ser transcrito, no caso das entrevistas, devem respeitar a legislação no que se refere ao direito à imagem e à autoria, através da assinatura por parte da pessoa entrevistada, filmada ou fotografada, em Carta de Cessão de Direitos direcionada ao LABOME. No caso das entrevistas, o pesquisador deve se responsabilizar pela primeira versão da transcrição, um funcionário ou estagiário do LABOME deve fazer uma primeira revisão, padronizando o documento de acordo com o formato definido pelo laboratório, e o pesquisador deve definir a versão final. Toda entrevista e imagem é acompanhada com "Cadastro de Entrevista" ou Ficha de Catalogação da Imagem, com informações sobre o cotexto de produção, técnica, envolvimento entre pesquisador e pesquisado, interesses específicos e processo de produção do documento.

Adotamos as temporalidades do documento discutidas no arquivismo e adaptamos ao nosso caso, pensando o documento corrente como aquele que está vinculado a um projeto em andamento, mas não tem ainda a referida carta de cessão de direitos. Neste caso, não é permitida a consulta. Somente o pesquisador e o entrevistado têm o direito de usar. $\mathrm{O}$ documento intermediário é aquele vinculado a um projeto finalizado no seu prazo de vigência, mas não tem ainda a carta de cessão de direitos. Neste caso, avaliamos a melhor forma de conseguir a autorização. Ainda não aconteceu casos de descartes, mas, não ter autorização não permite o uso público do documento. No LABOME, se entende por acervo permanente, aquele documento que tem carta de cessão de direitos, independente do projeto estar finalizado ou em andamento. 
Infelizmente, não é prática massificada no campo das ciências sociais, o pedido de autorização. Neste caso, muitos documentos encontram-se ainda no acervo intermediário, resultantes de projetos finalizados. Outro problema que o LABOME enfrenta é a pouca consulta ao acervo. Em 2009, avaliando a pouca procura e o mínimo interesse por acervos da natureza que dispomos, criamos um programa de extensão com alguns colegas, chamado Visualidades ${ }^{26}$, como já descrito na primeira parte deste artigo.

Neste caso, a inserção social não se dá somente via Visualidades, mas também via constituição de acervos no LABOME. A documentação não é usada somente para produção de filmes no formato de documentários, apesar de ser uma prática muito corrente. No ano de 2017, a título de exemplo, dois grupos vêm sendo apoiados para produção de pequenos vídeos de divulgação nas redes sociais: o Movimento Social Fome, que promove o evento Batalha do T. N. (bairro Terrenos Novos) ${ }^{27}$ que consiste em batalha de rappers locais, iniciantes e veteranos; e o Slam da Quentura, ${ }^{28}$ que organiza saraus de poesia, especialmente com moradores da periferia. Ambos são coletivos de jovens que se organizam para mostrar suas artes. Apoiamos na produção audiovisual e eles divulgam suas atividades. Ao mesmo tempo produzimos acervos documentais para consulta pública.

Também pensando no incremento do acervo, desenvolvemos projeto "Narrativas e imagens: bairros e cidades possíveis em Sobral/CE" financiado pelo Programa de Bolsas de Produtividade em Pesquisa e Estímulo à Interiorização BPI - EDITAL No 09/2015 da FUNCAP, que, além de apoiar os projetos de audiovisual vinculados ao tema do patrimônio cultural, valorizando ampliar e criticar conceitos que tendem a homogeneizar culturalmente habitantes de uma cidade e padronizar uma identidade cultural estável, em que foi possível realizar um trabalho com os moradores do bairro periférico Vila União, em parceria com o Laboratório de Geoprocessamento da UVA, projeto esse batizado de "Mapa Digital da Comunidade". Este último consiste em disponibilizar um aplicativo para celular que seja uma espécie de rede social com mapa onde o usuário pode ver pontos marcados com GPS e, ao clicar nestes pontos, ele possa ter acesso a imagens fotográficas do local e depoimento em áudio do morador

\footnotetext{
${ }^{26}$ Os professores envolvidos inicialmente foram Paulo Passos de Oliveira e Regina Celi Fonseca Raick. Nos anos seguintes, vários professores passaram a integrar a equipe.

${ }^{27}$ Cf. página no Facebook: https://www.facebook.com/BatalhadoT.N/?hc_ref=ARSaw XEea_j4v8 DIP9NvCUw3tCExtrO6jQHPLhKyR1BaF496c9YrxnCOLYv-6OOnCTc.

${ }^{28}$ Cf. página no Facebook: https://www.facebook.com/slamdaquentura/.
} 
explicando que atividade desenvolve, a história deste envolvimento e comentários sobre a realidade do bairro.

Para realização do "Mapa digital da Comunidade" fomos de casa em casa para produzir estas informações de partida que vão ser incluídas no programa, mas o aplicativo permite que o próprio morador faça a marcação de seu local e atividade com foto, áudio e texto, abrindo espaço também para eventos e atividades. O morador poderá também comentar os pontos marcados no aplicativo por outras pessoas. A proposta é que o morador possa se apoderar melhor de seu espaço, usando este recurso como instrumento. A ideia é que possamos dar continuidade, ampliando os bairros atendidos. Além do aplicativo, o morador terá acesso a DVD-rom que, apesar de limitar mais a interação, também poderá ser instrumento de decisão sobre as formas de ocupação do espaço. Ao mesmo tempo, o acervo do LABOME é incrementado com novas entrevistas e imagens. No IX Visualidades, uma das exposições mostra um pequeno fragmento deste projeto através de fotografias.

Além deste projeto, apoiamos os filmes: "A Face do Preconceito", produzido por bolsistas do PIBID/História/UVA e dirigido por Francisco de Souza Lima Filho; "Afetos de Reisado", de Antônio Jarbas Barros de Moraes, aluno do Mestrado Acadêmico em Geografia; "Dia de feira" de Luiz Antônio Araújo Gonçalves e Virgínia Célia Cavalcante de Holanda; ambos professores do Curso de Geografia; "Eu sou mulher", de Telma Bessa e Mariana Dantas, professoras do Curso de História; "Mãe Lagoa”, de Philipi Emmanuel Lustosa Bandeira e José Osmar Fonteles, professores da área de Ciências Sociais; e "RAP nas quebradas", de Kélia Viana, já citado neste artigo. Dentre as exposições fotográficas tivemos os seguintes trabalhos apoiados pelo LABOME: "Cartografando: Olhares, sorrisos e experiências da cartografia social no Bairro Vila União Sobral/Ce", trabalho coletivo já citado neste artigo; "Hora do Show, Hora do Trampo. Aplausos Para Elxs!” de Joyce Ramos, projeto este que também está sendo realizado em função de um documentário ainda na fase de montagem; "O Que fica Nos Escombros" de Renan Dias, também sendo realizado em função de um documentário na fase de montagem; e "Quando eu Crescer Quero ser Criança", outra exposição que acompanha a produção de um filme sobre diferentes velhices na cidade.

Diante do exposto, resta dizer que o LABOME e o Visualidades pretendem, nos anos seguintes, incrementar suas atividades, ampliar o intercâmbio interinstitucional e inserção social para além do que já alcançamos até o presente momento. Sabemos que é uma construção possível, mas é uma luta constante, árdua e, diante da conjuntura do 
país, muito complicada. A briga pela inserção social de nossas atividades é constante e negociada cotidianamente. É um espaço cambiante, cheio de lacunas, com variações e territorializações contínuas que pretendemos continuar explorando e desenvolvendo nos trabalhos que desenvolvemos no LABOME e no Visualidades.

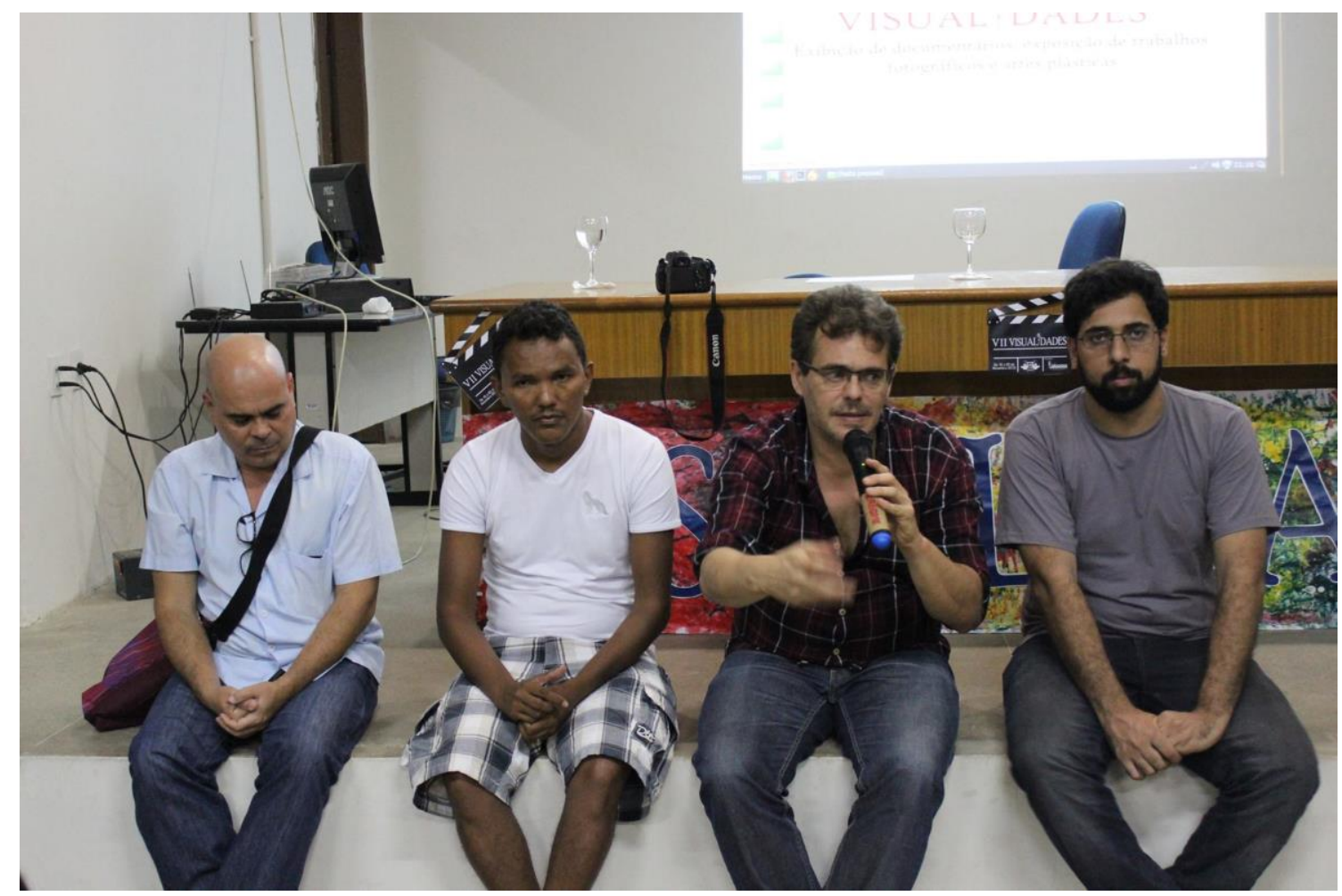

Foto 1: Abertura do VII Visualidades com presença do professor Alexandre Fleming (UFC).

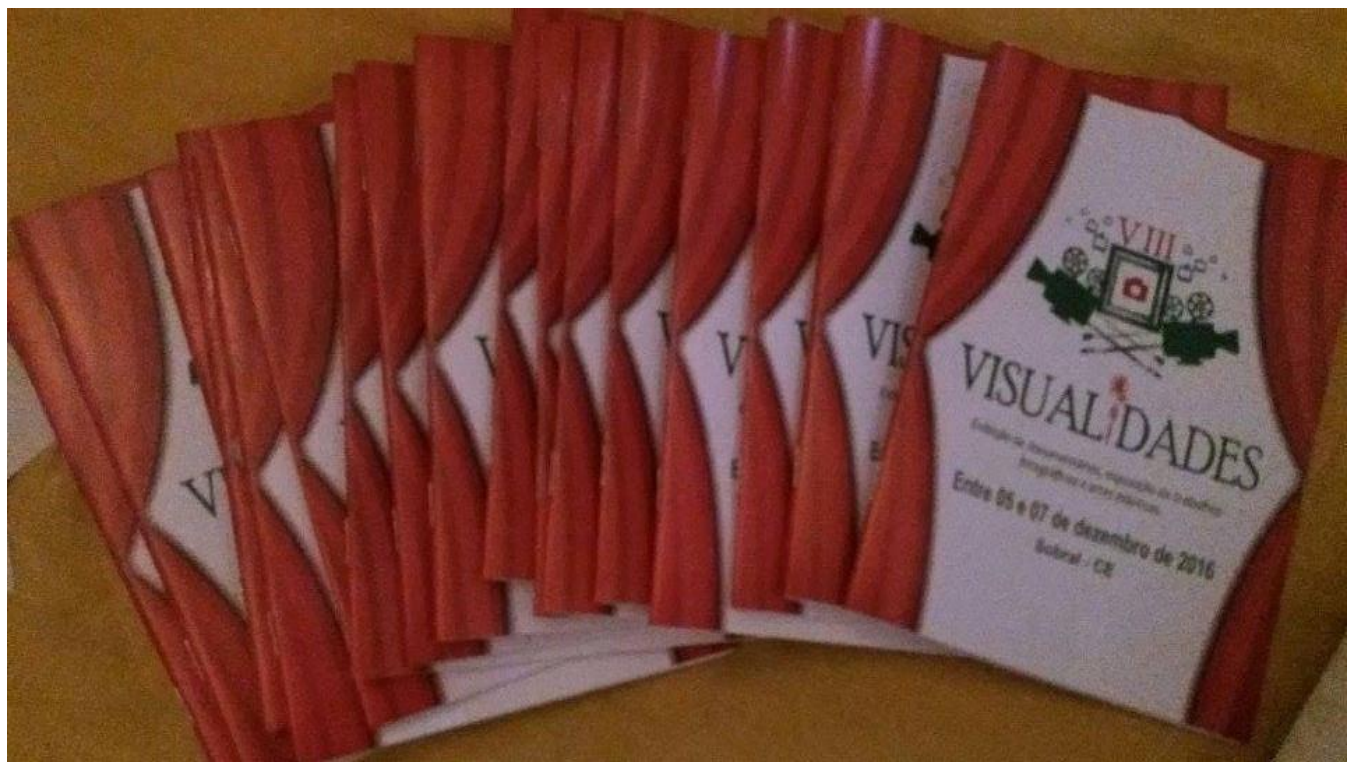

Foto 2: Catálogo do VIII Visualidades. 


\section{OFIIINA DE PRODUCÃO DE
DOCUMENTTARIOS \\ 。品 VI吊口。 0 \\ VISUALEDADES 9 \\ Inscrições no Labome- $\mathrm{CCH}$ : de 05 a 16 de maio

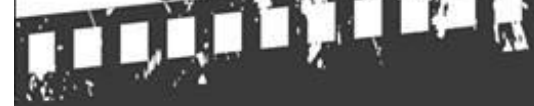

$1^{\circ}$ módulo: (início dia 20 de maio):

- Roteiro - 30 horas/aulas;

- Pré-Produção (pesquisa e orientação teórica) - 30 horas/aulas.

$2^{\circ}$ módulo:

- Iluminação - 15 horas/aulas;

- Captação de áudio - 15 horas/aulas;

- Fotografia para documentários - 30 horas/aulas

$3^{\mathrm{a}}$ módulo:

- Edição e montagem - 30 horas/aulas - dia terça entre 14:00 e 18:00 horas.

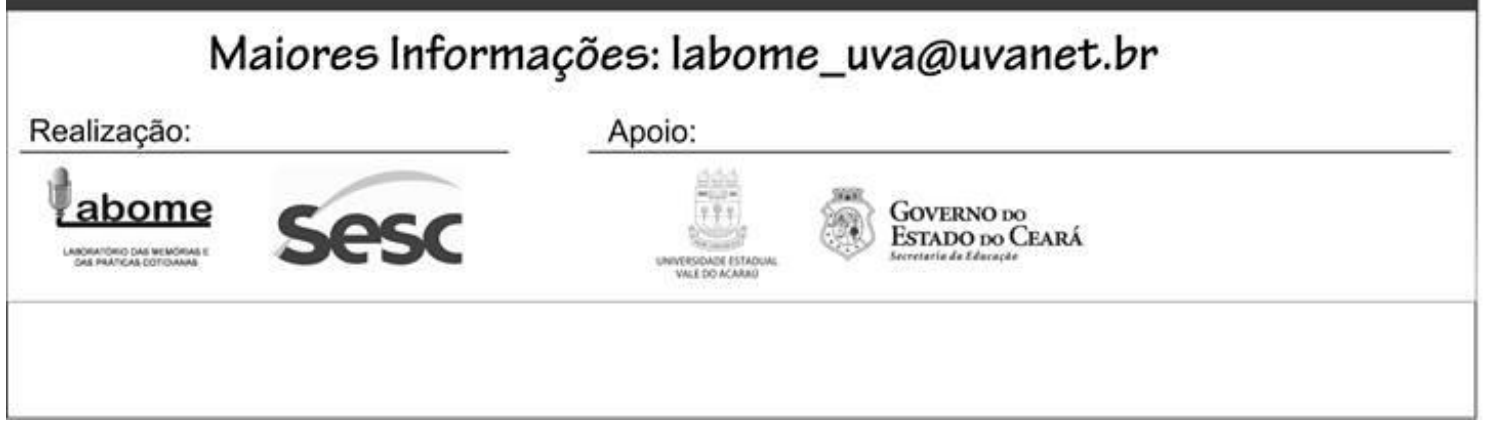

Foto 3: Curso de formação ofertado em 2014. 


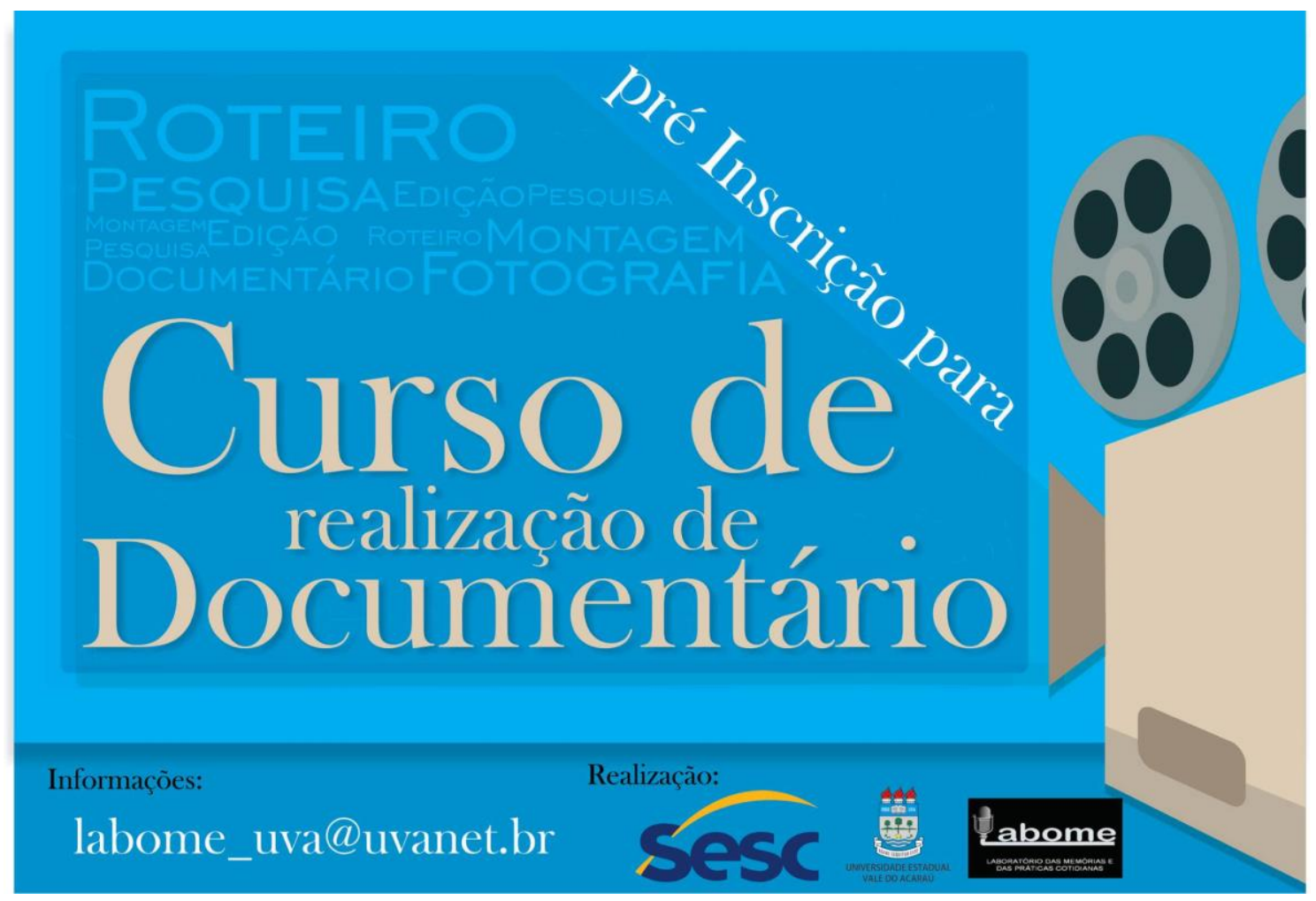

Foto 4: Curso de Realização de documentários ofertado em 2015.

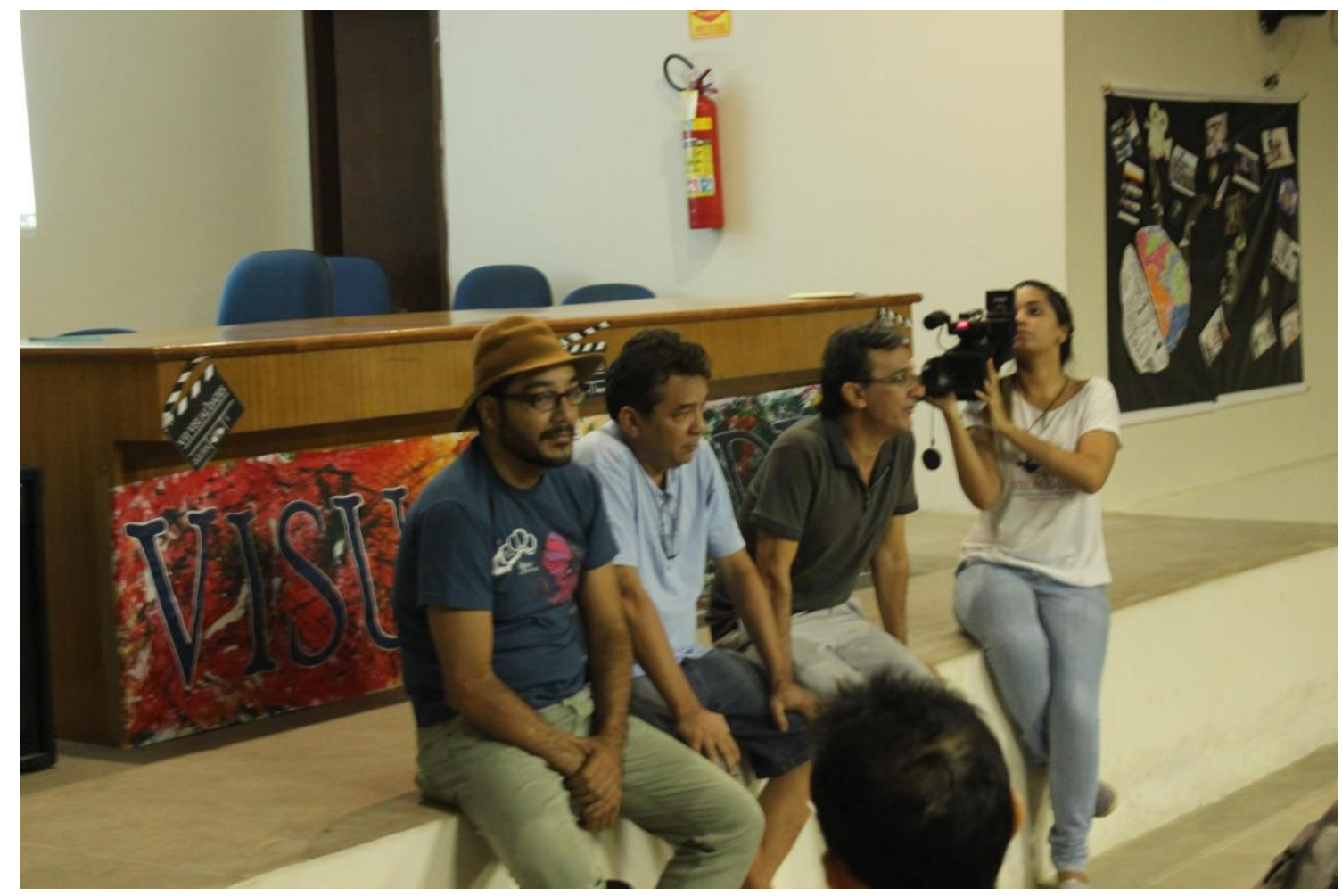

Foto 5: Debate com produtores dos documentários após exibição no VII Visualidades. 


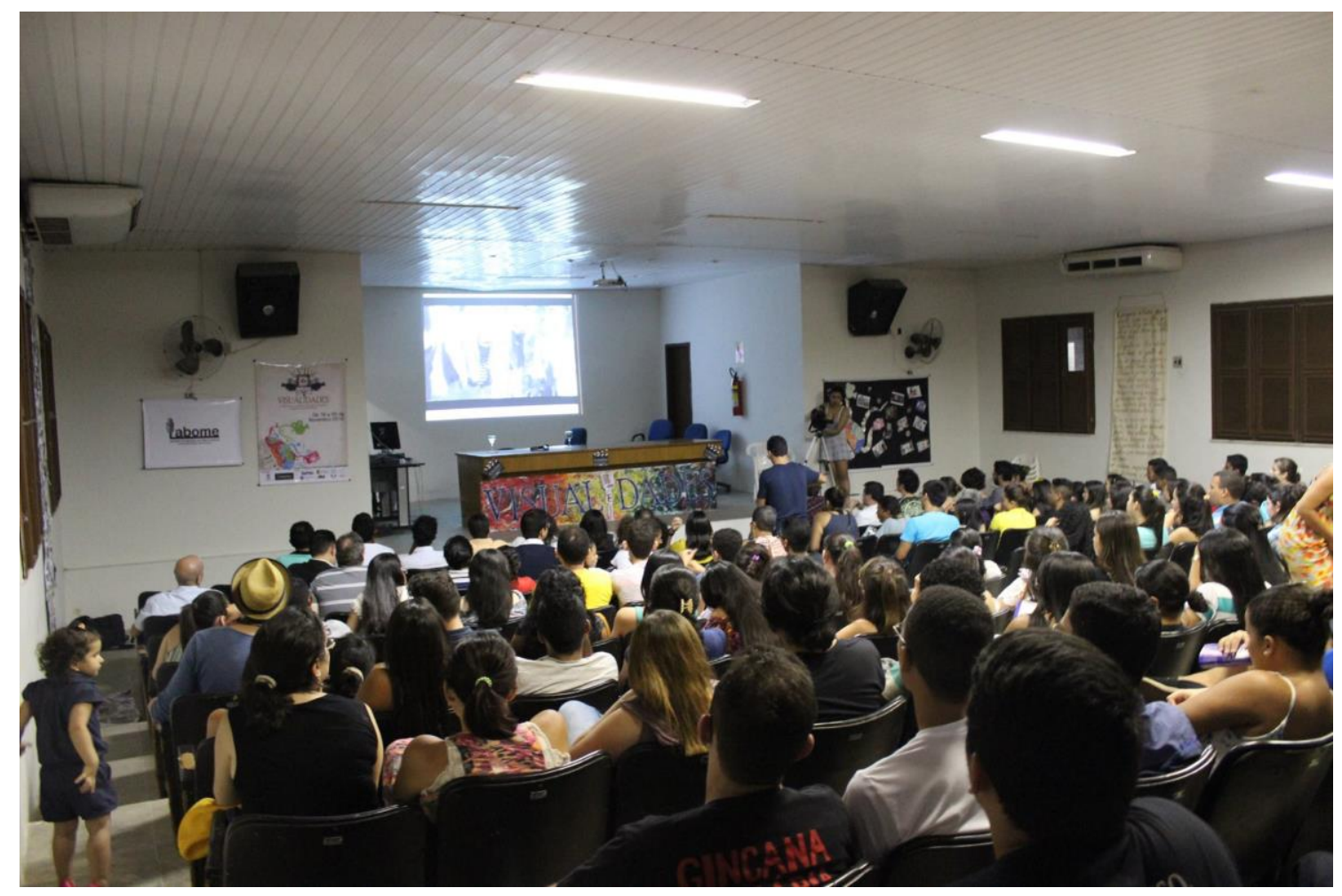

Foto 6: Exibição de filmes no VII Visualidades.

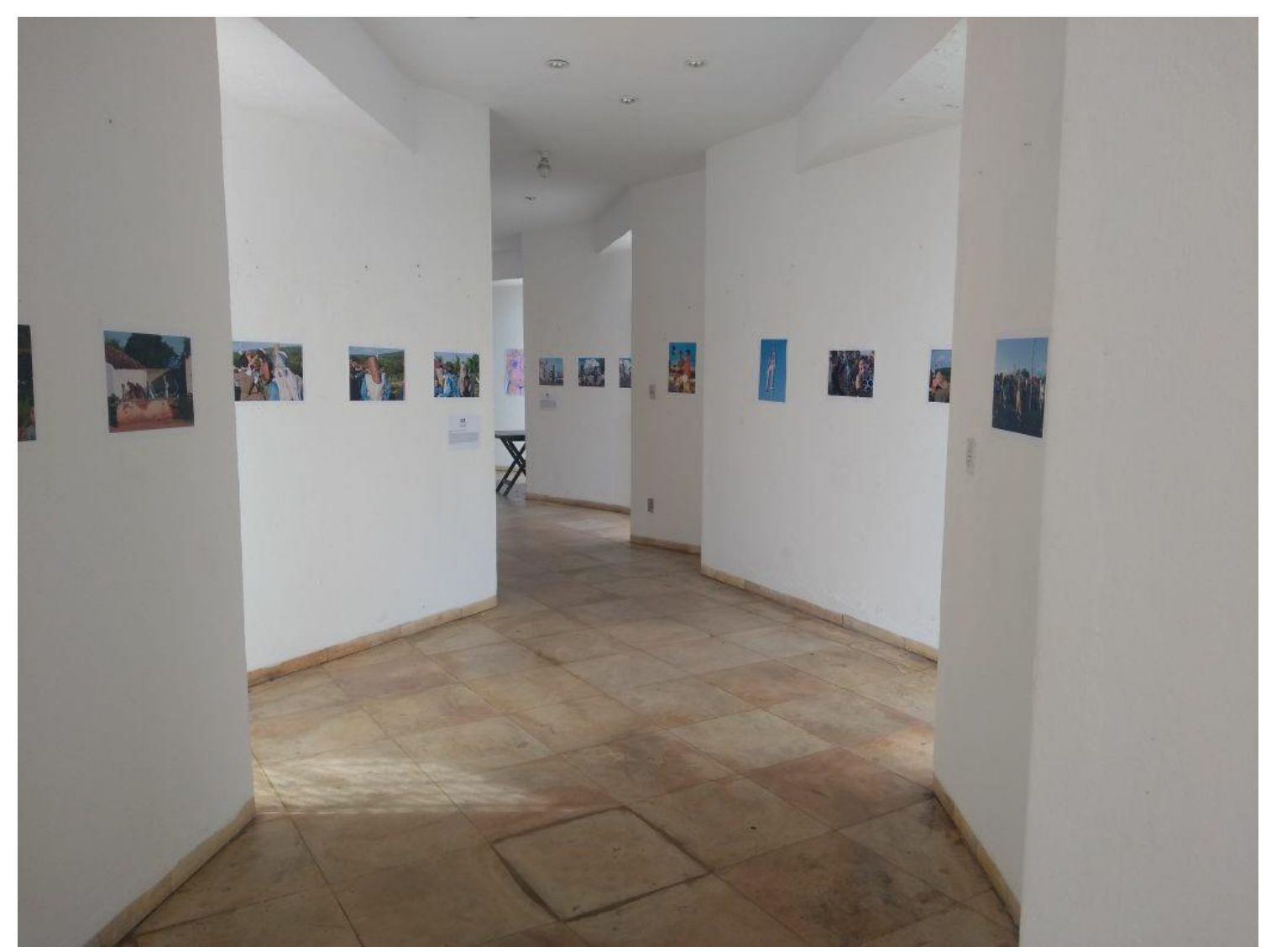

Foto 7: Exposição de fotografias do IX Visualidades. 


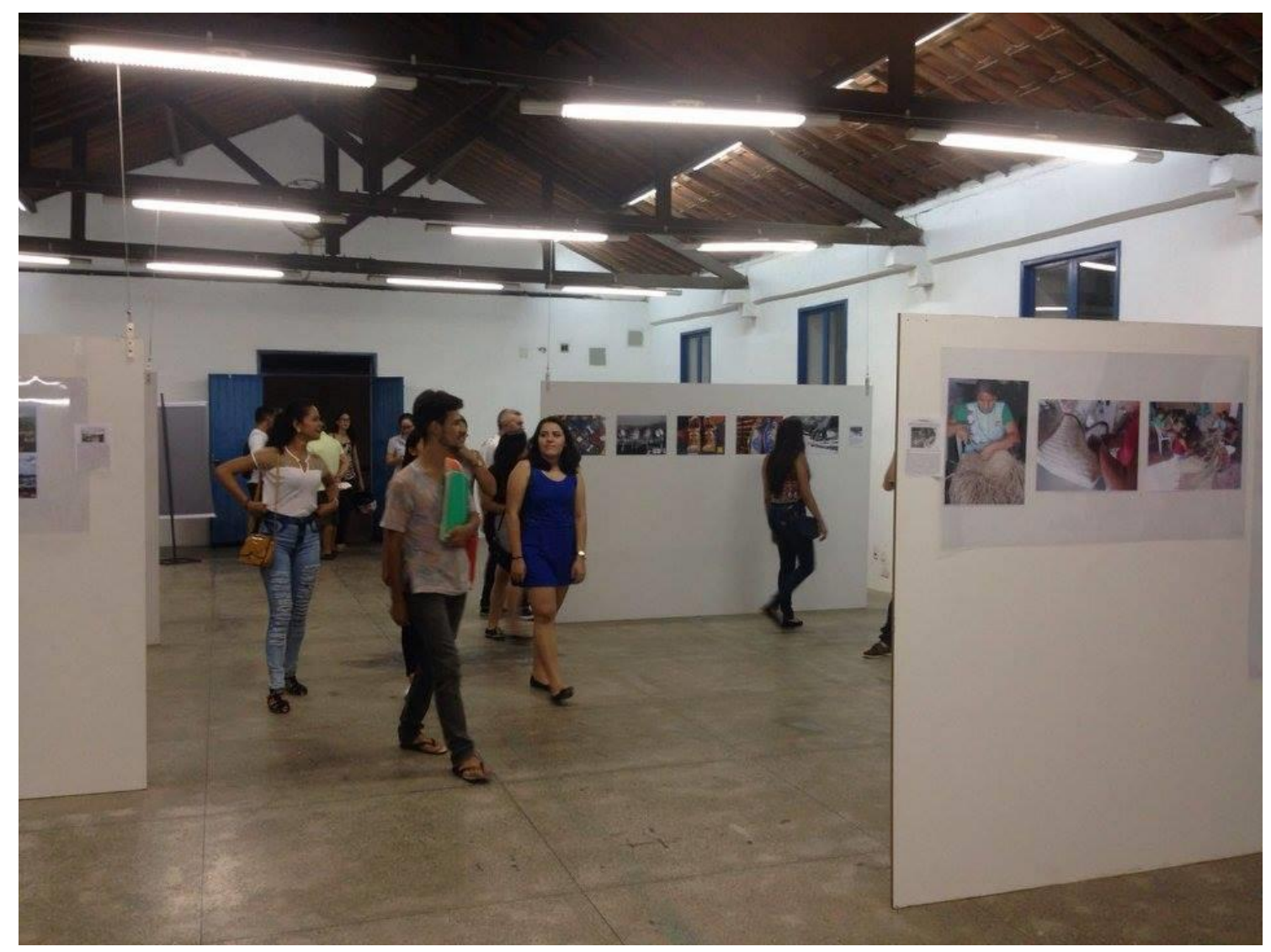

Foto 8: Exposição de fotografias no VIII Visualidades.

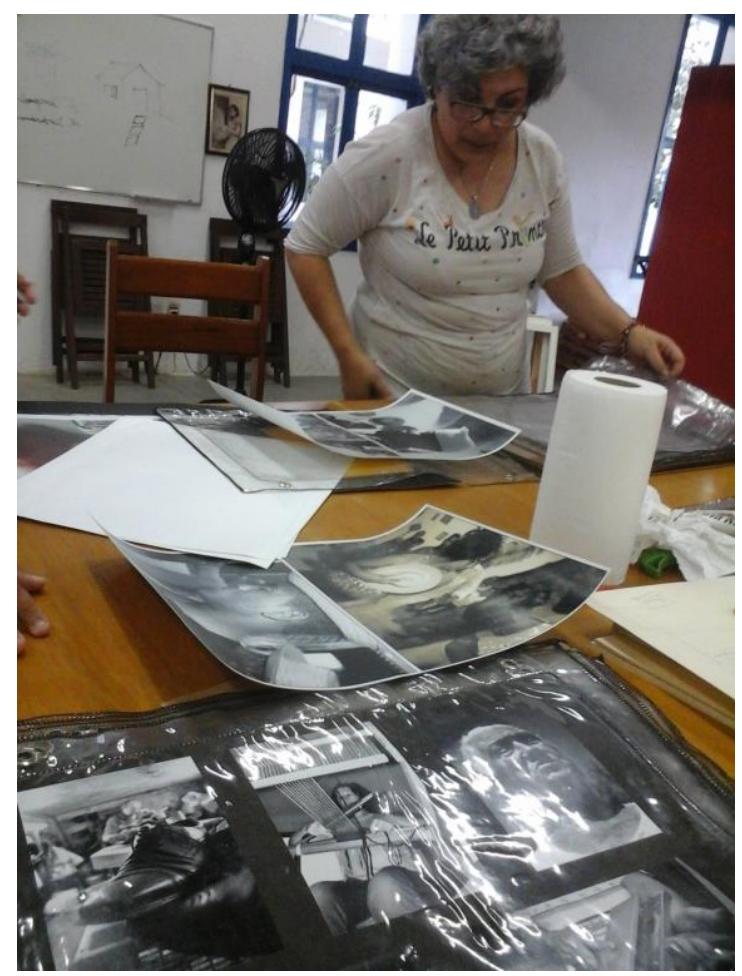

Foto 9: Montagem da exposição no VI Visualidades em 2014. 


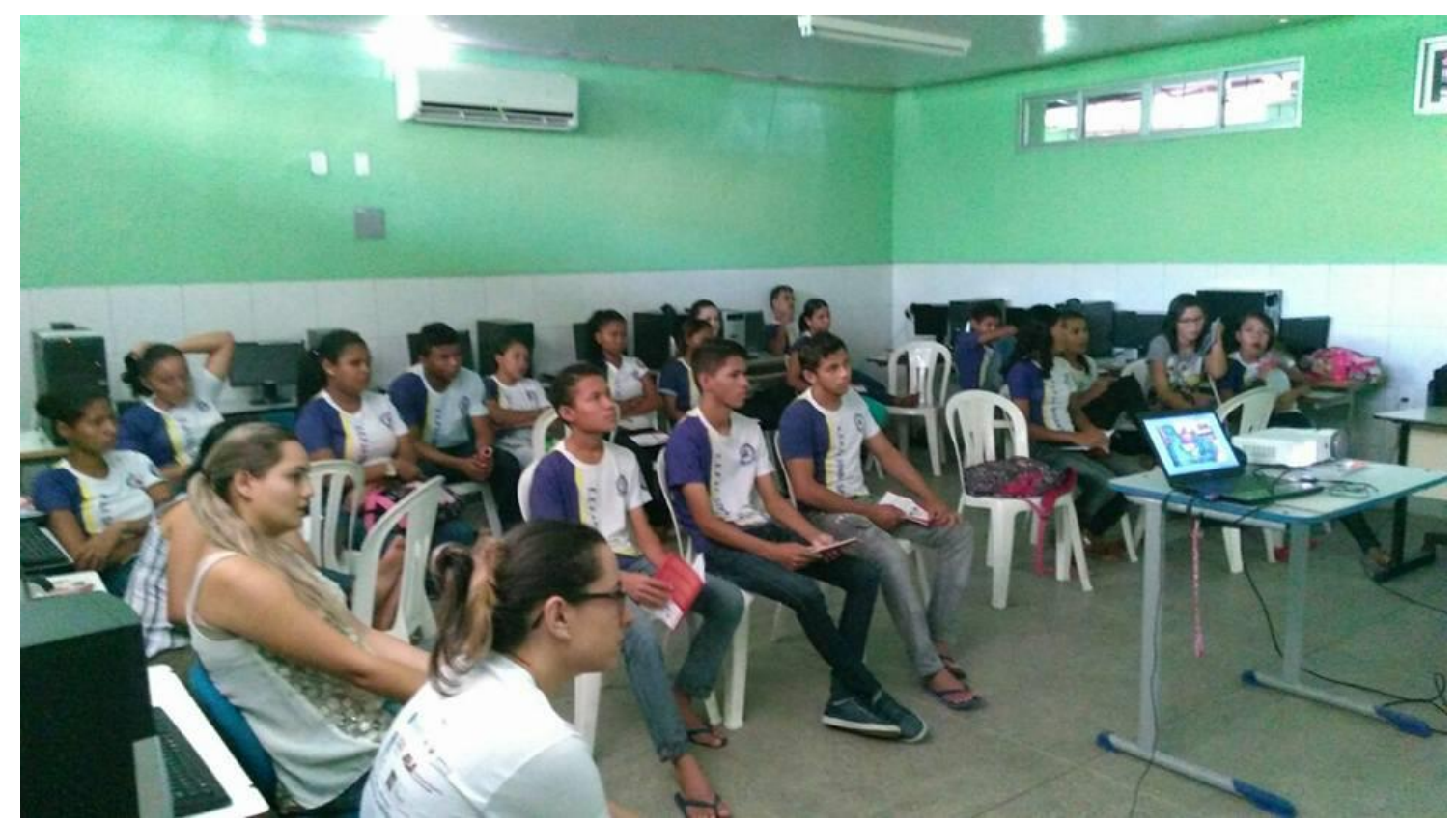

Foto 10: Mostra em escolha de ensino fundamental e médio no VIII Visualidades (foram 21 lugares nas cidades de Sobral, Ipú, Cariré, Viçosa do Ceará, Pacujá, Graça, Ibiapina, Moraújo, Marco e Hidrolândia).

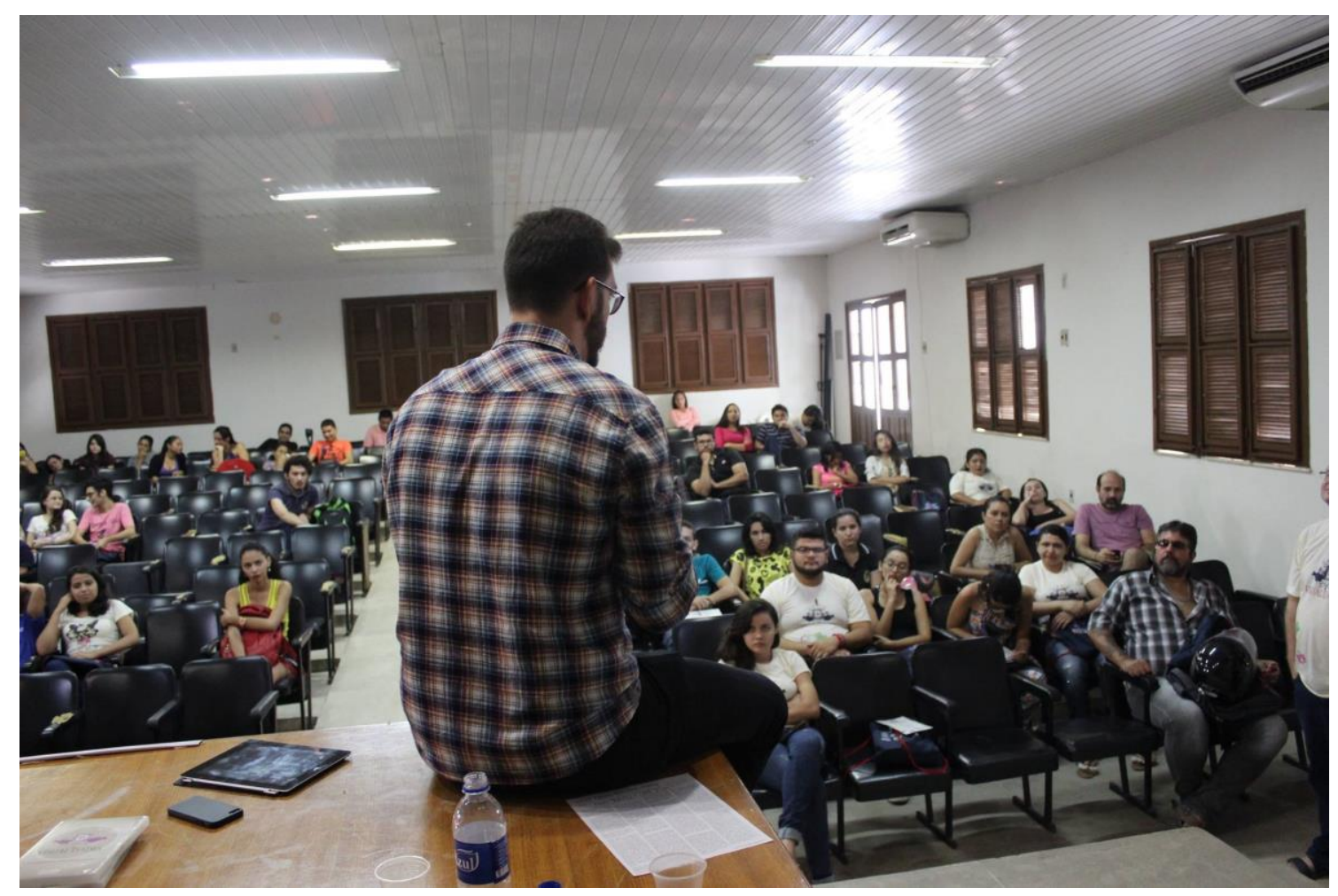

Foto 11: Oficina com Vitor Grunvald no VII Visualidades. 


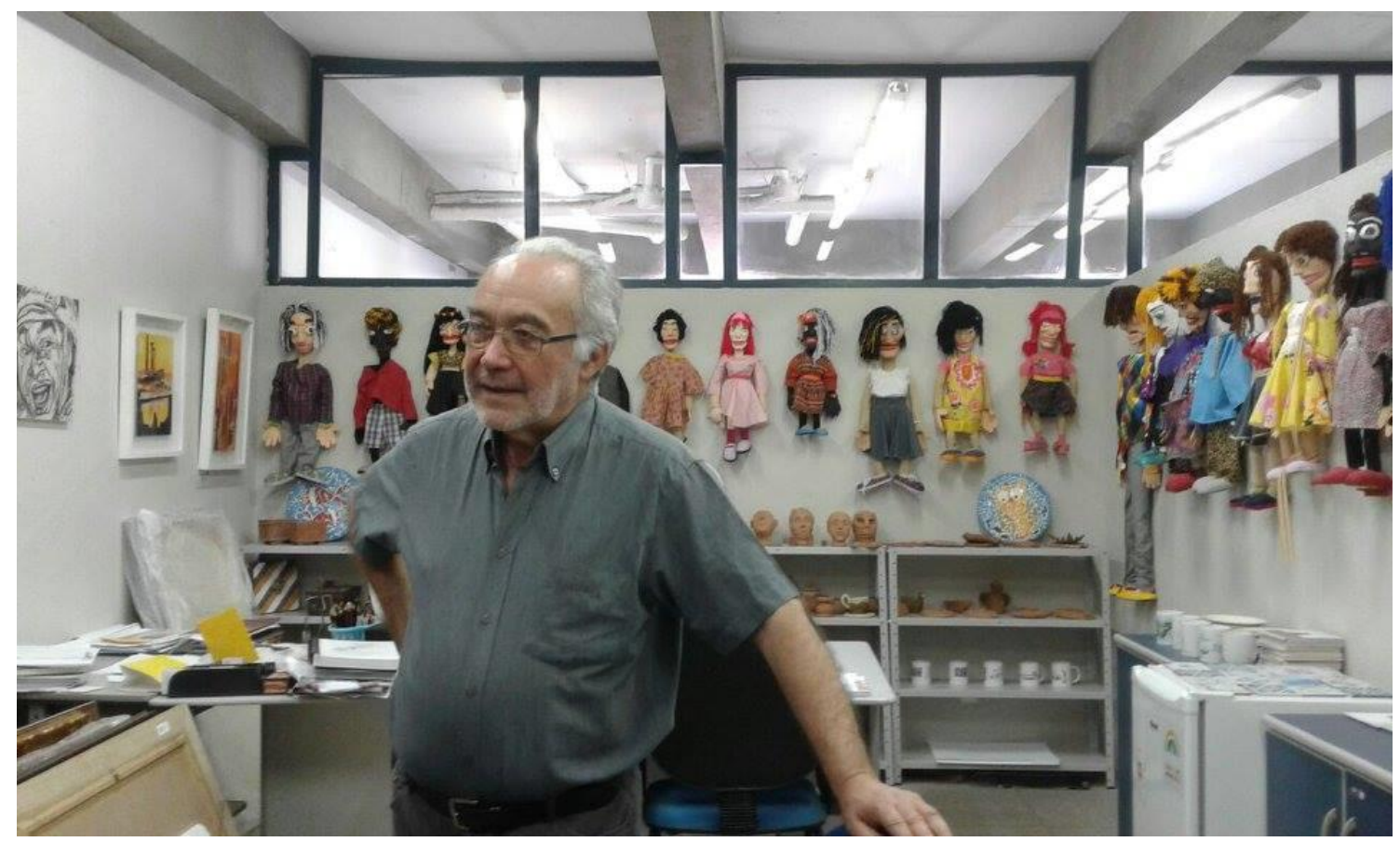

Foto 12: Professor José Ribeiro (Universidade Aberta de Lisboa) esteve presente no VIII Visualidades.

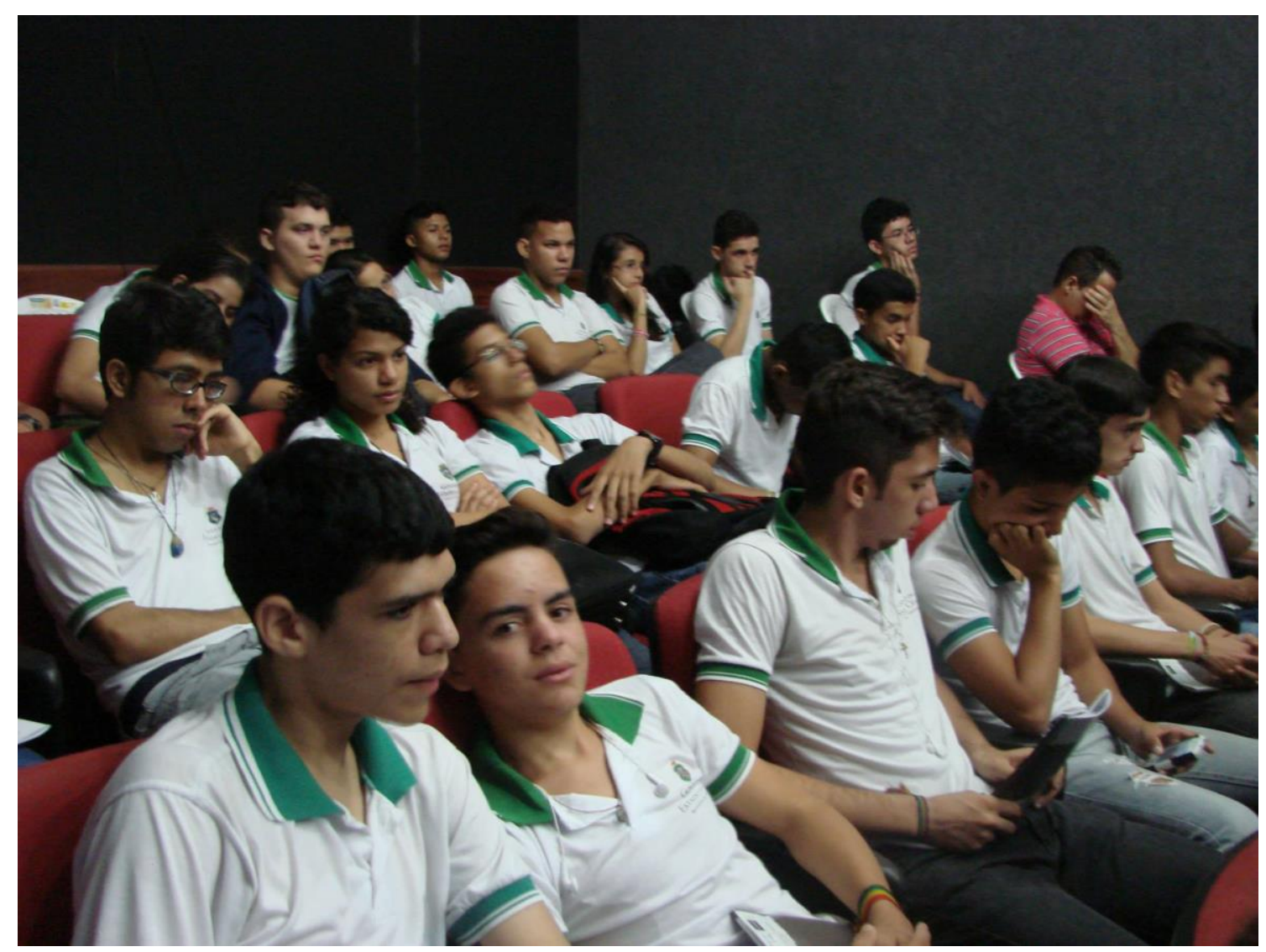

Foto 13: Abertura do VI Visualidades com alunos do Curso de Áudio e Vídeo da Escola Liceu de Sobral. 


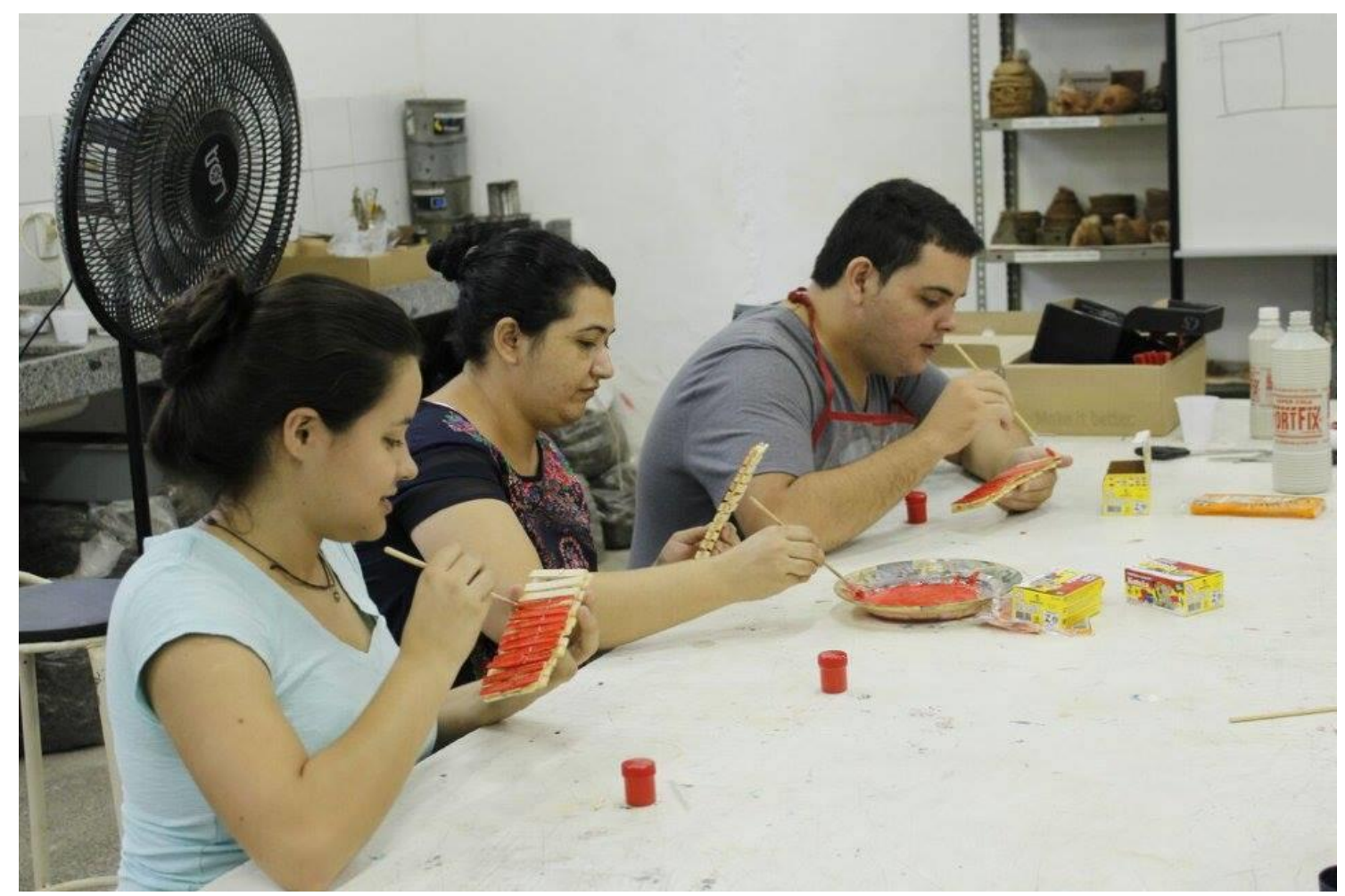

Foto 14: Oficina de ambientação com artes visuais do VII Visualidades.

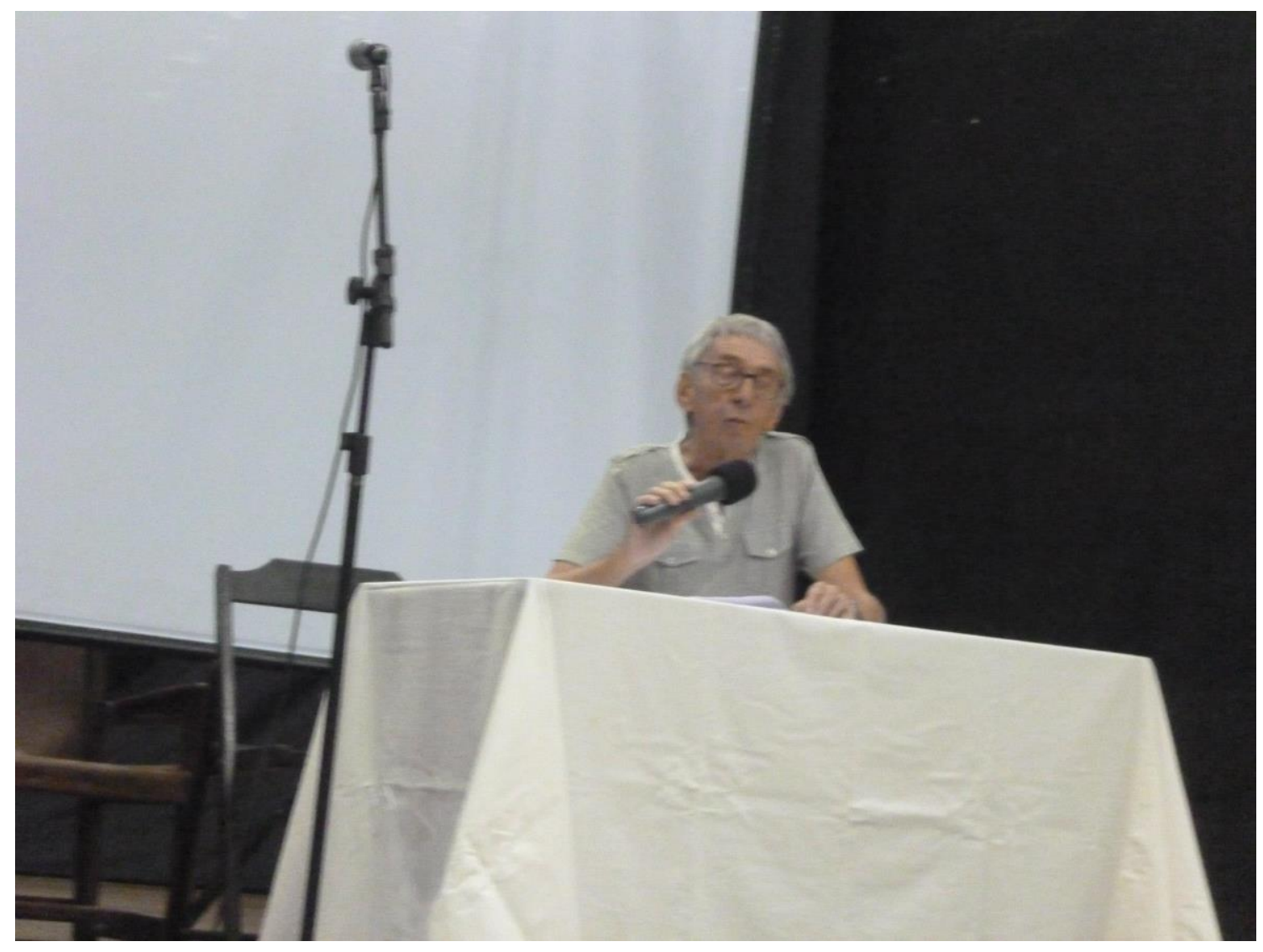

Foto 15: Presença do professor Etienne Samain (UNICAMP) no Visualidades de 2012. 


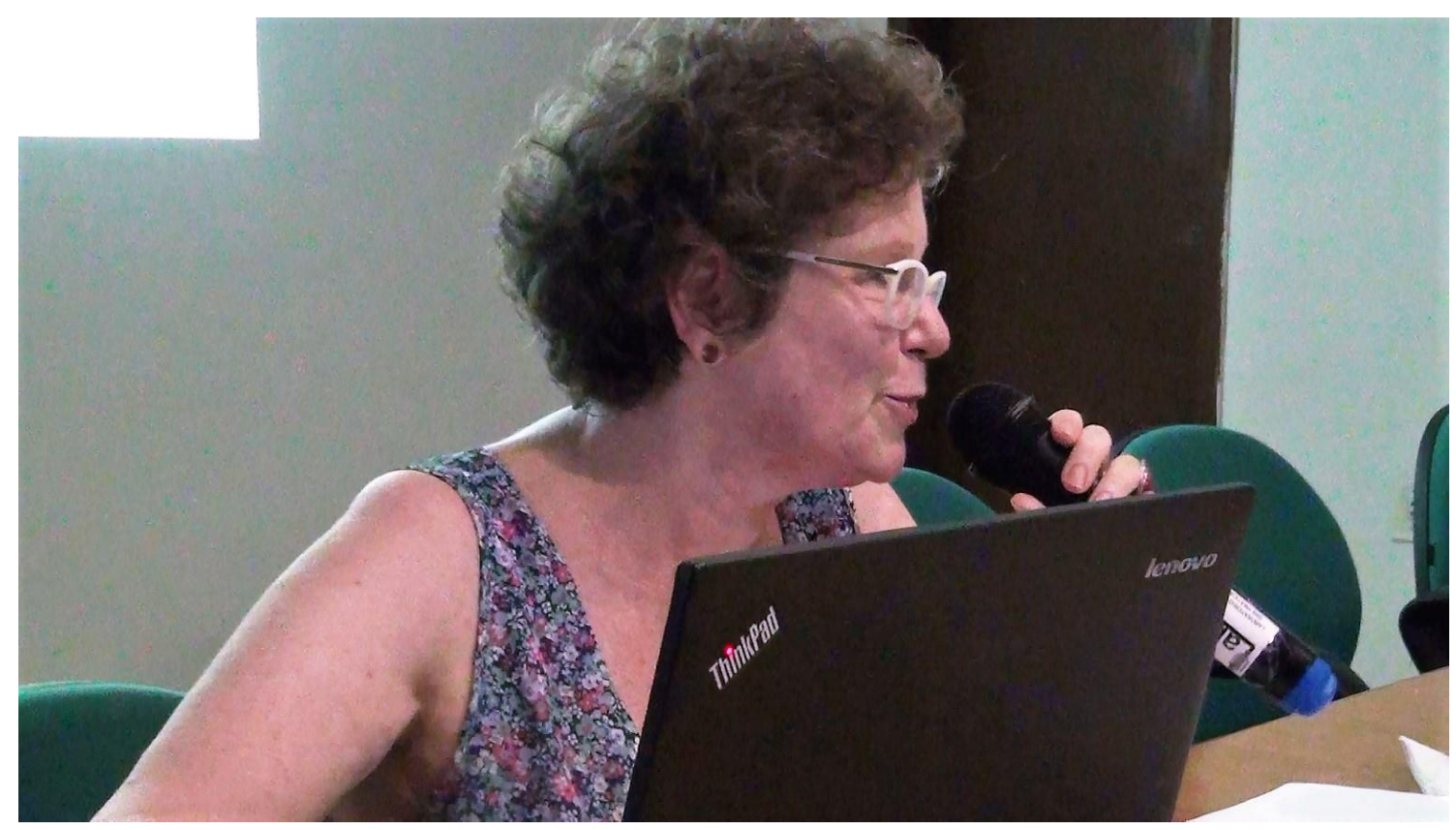

Foto 16: Professora Cornélia Eckert no IX Visualidades.

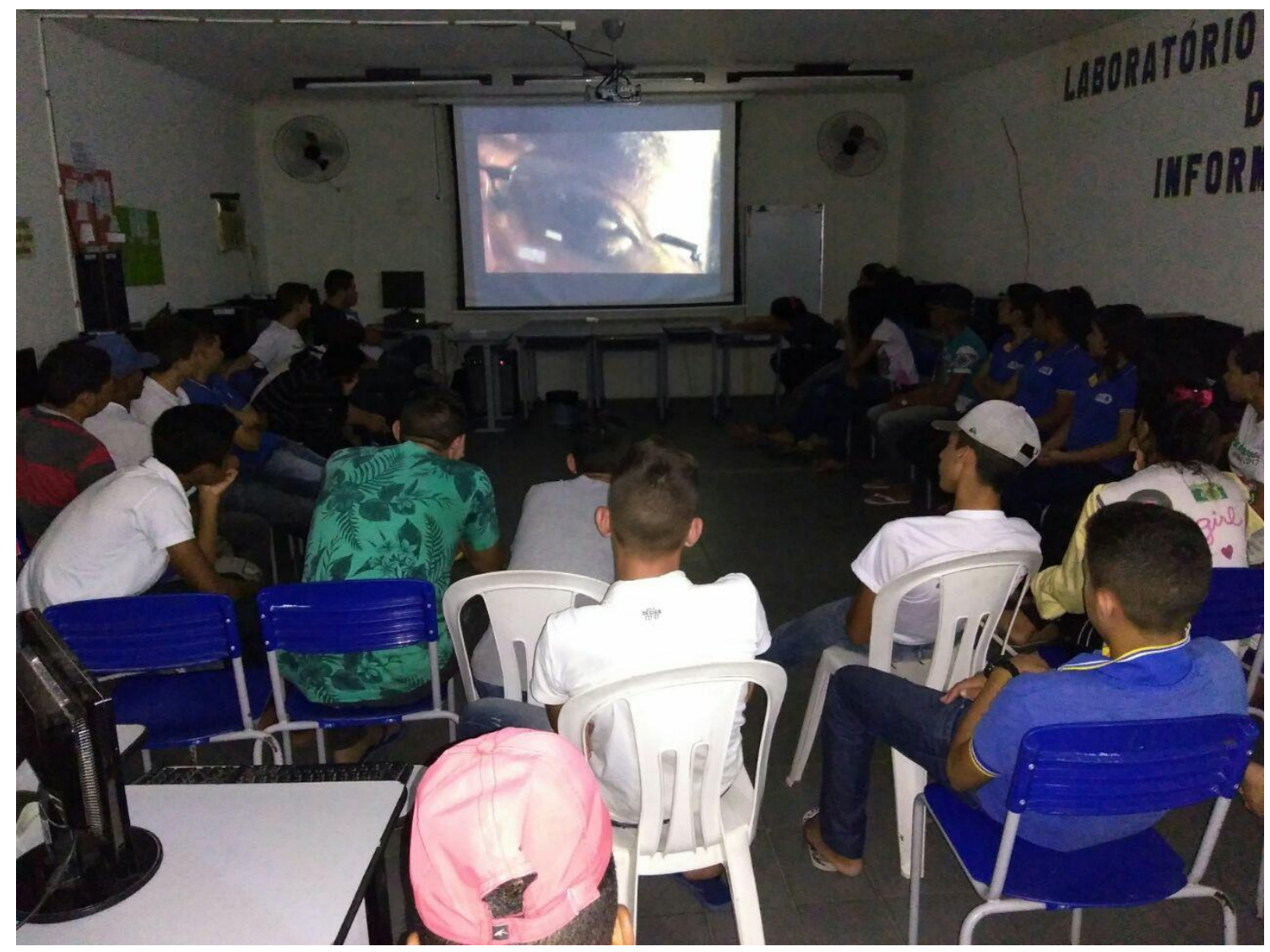

Foto 17: Exibição de filmes do IX Visualdiades nas escolas (foram 33 lugares e 12 cidades, incluindo o Rio de Janeiro). 


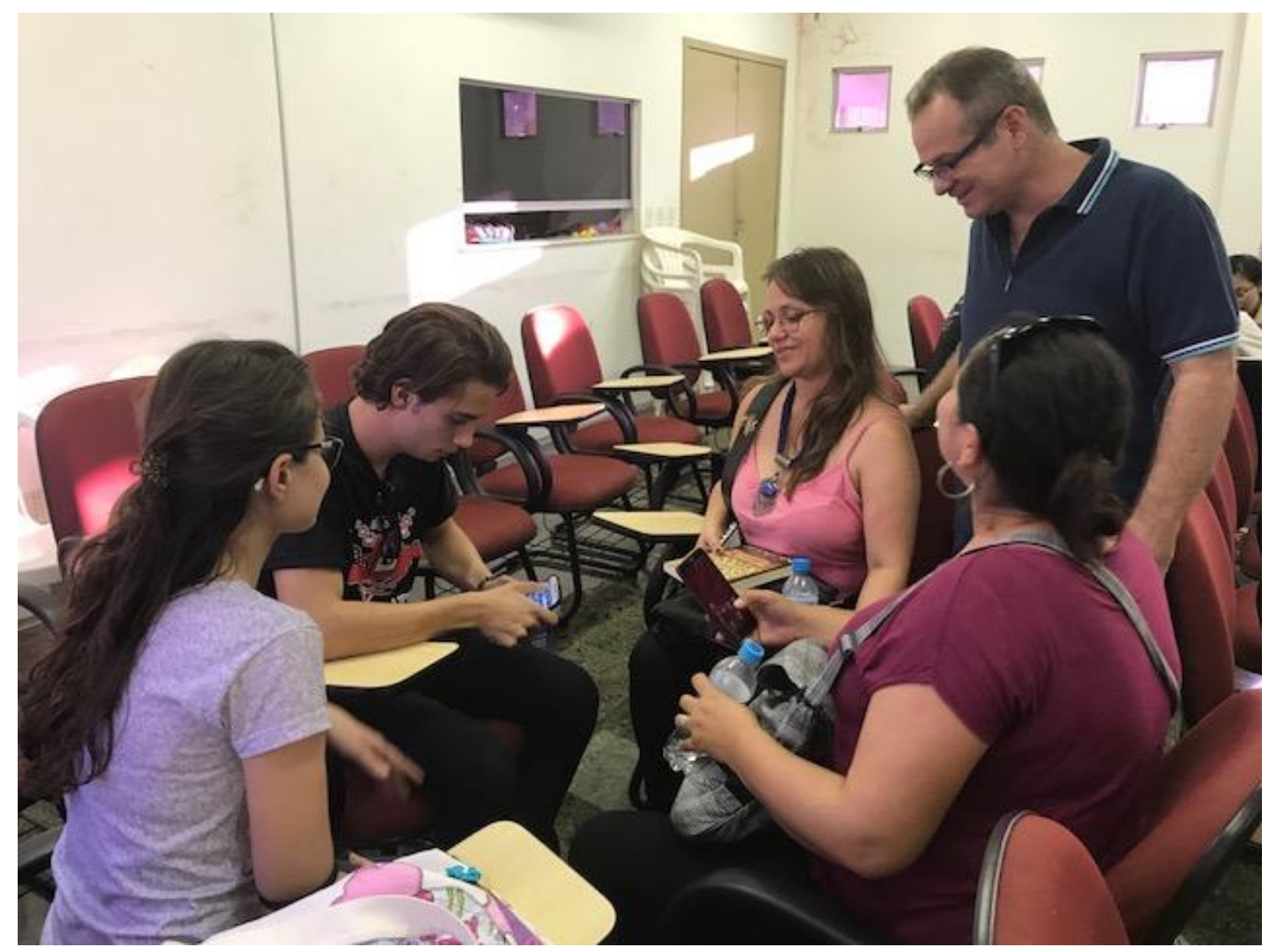

Foto 18: Prof. Nilson Almino de Freitas observando o resultado da edição de vídeo da equipe na oficina de narrativas com imagens. 4 dezembro 2017, foto Cornelia Eckert.

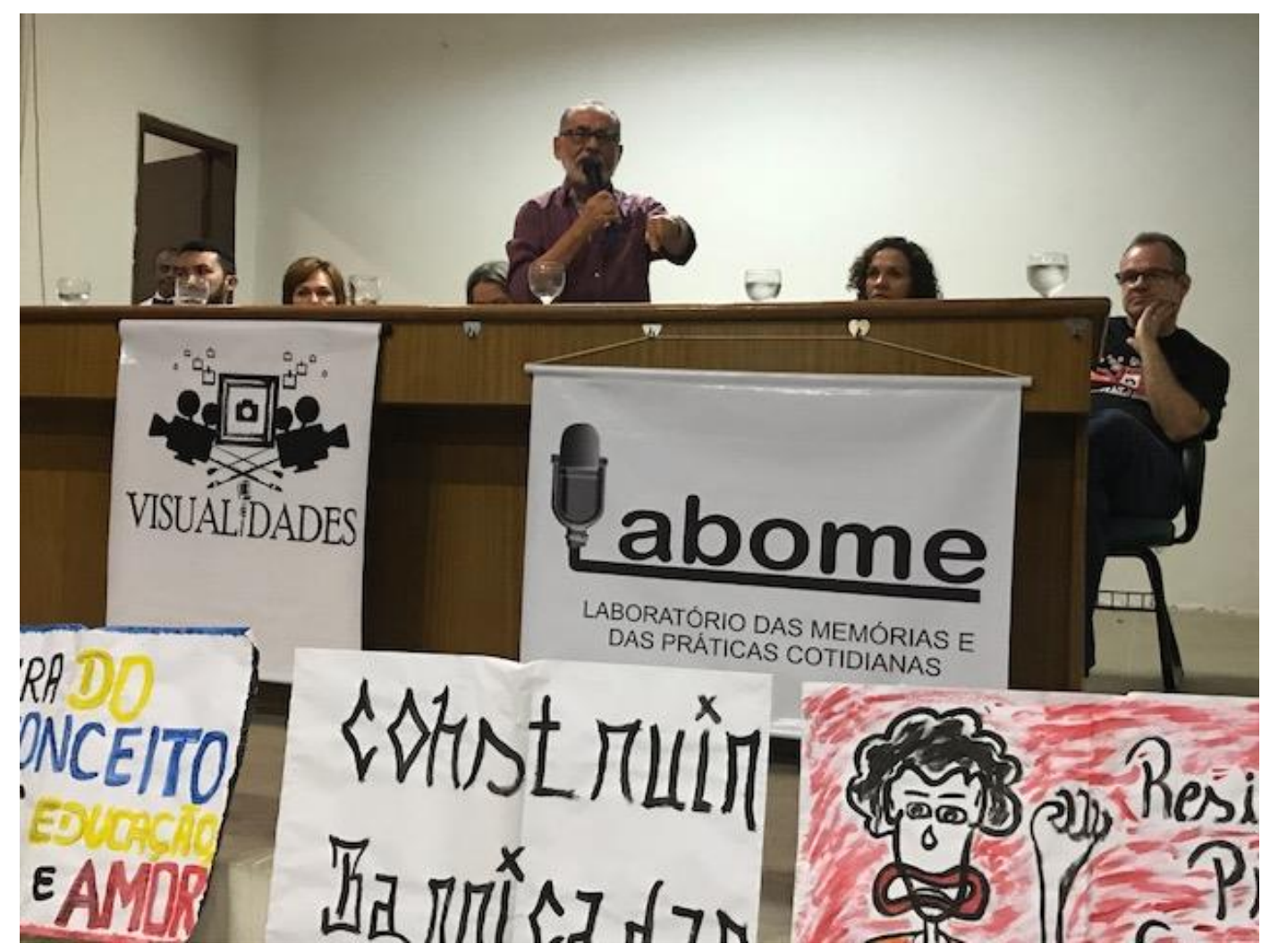

Foto 19: Abertura do IX Visualidades. UVA, Sobral-CE, 4 dezembro 2017, foto Cornelia Eckert. 


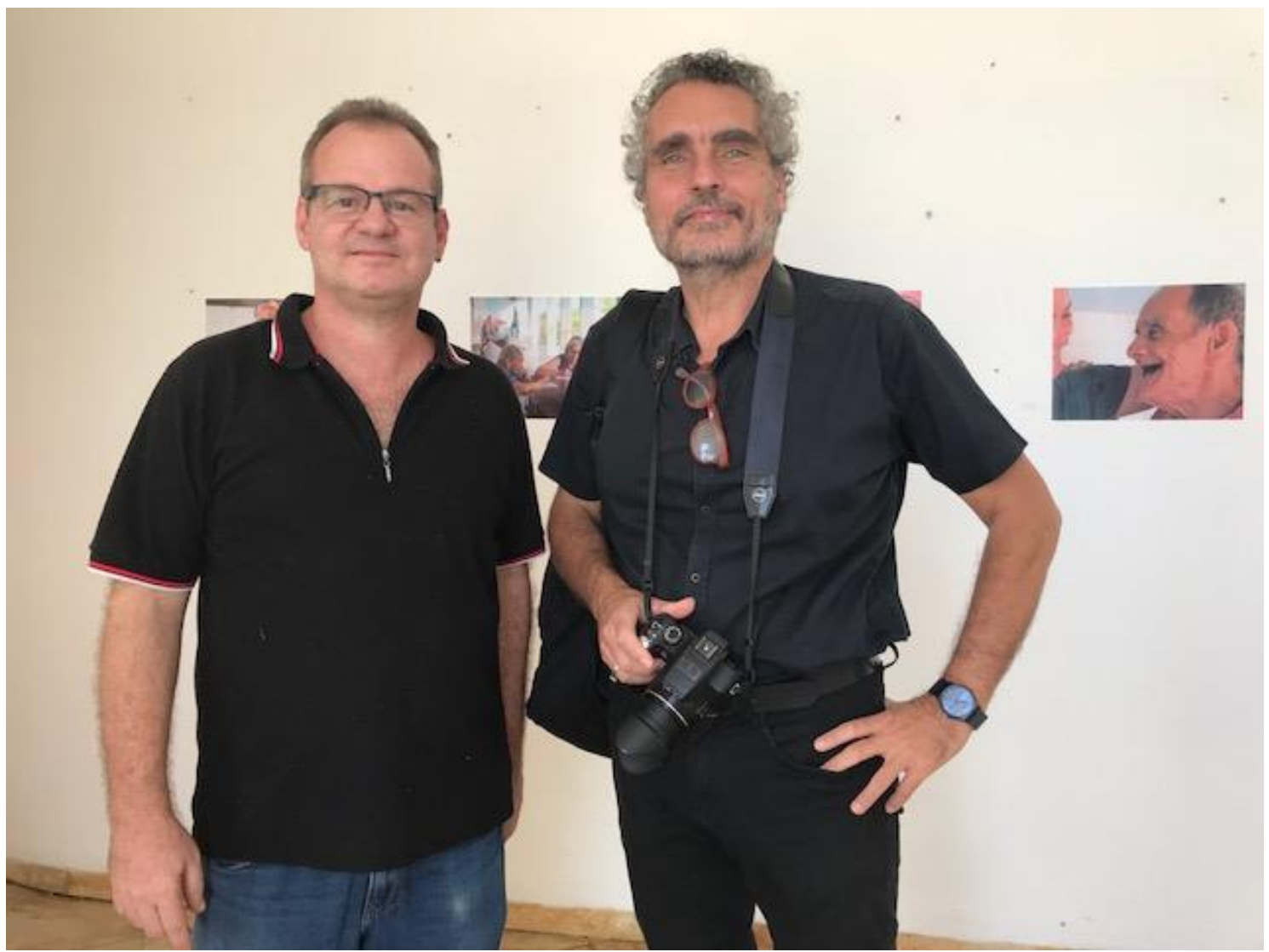

Foto 20: Prof. Nilson Almino de Freitas, coordenador do IX Visualidades e Prof. Marco Antônio Gonçalves da UFRJ, foto Cornelia Eckert.

\section{Referências}

FONSECA, Cláudia. A noética do vídeo etnográfico. Horizontes Antropológicos. Porto Alegre, ano 1, n. 2, p. 187-206, jul./set. 1995

GONÇALVES, Marco Antônio e HEAD, Scott. Confabulações da Alteridade: imagens dos outros (e) de si mesmos. In.: GONÇALVES, Marco Antônio e HEAD, Scott (Org.). Devires Imagéticos: a etnografia, o outro e suas imagens. Rio de Janeiro: 7letras, 2009. RIAL, Carmem Silvia de Moraes. (2016). Roubar a alma - ou as dificuldades da restituição. In: VAILATI, Alex, GODIO, Matias, RIAL, Carmen (org.). Antropologia Audiovisual na Prática. Florianópolis: Desterro, [Florianópolis]: Cultura e Barbárie, 2016.

VALE, Alexandre Fleming Câmara. Por uma estética da restituição: notas sobre o uso do vídeo na pesquisa antropológica. Tessituras, Pelotas, v. 2, n. 2, p. 162-200, jul./dez. 2014.

Recebido em: 12/12/2017. Aprovado em: 17/12/2017. 